OPEN ACCESS

Edited by:

Edmundo Acevedo,

Universidad de Chile, Chile

Reviewed by:

Thomas D. Sharkey,

Michigan State University,

United States

Carmen Arena,

University of Naples Federico II, Italy

*Correspondence:

Laurent Urban

laurent.urban@univ-avignon.fr

Specialty section:

This article was submitted to

Plant Breeding,

a section of the journal

Frontiers in Plant Science

Received: 30 August 2017 Accepted: 20 November 2017 Published: 14 December 2017

Citation:

Urban L, Aarrouf J and Bidel LPR (2017) Assessing the Effects of Water Deficit on Photosynthesis Using

Parameters Derived from

Measurements of Leaf Gas Exchange and of Chlorophyll a Fluorescence.

Front. Plant Sci. 8:2068

doi: 10.3389/fpls.2017.02068

\section{Assessing the Effects of Water Deficit on Photosynthesis Using Parameters Derived from Measurements of Leaf Gas Exchange and of Chlorophyll a Fluorescence}

\author{
Laurent Urban $^{1 *}$, Jawad Aarrouf ${ }^{1}$ and Luc P. R. Bidel ${ }^{2}$ \\ ${ }^{1}$ UMR 95 Qualisud/Laboratoire de Physiologie des Fruits et Légumes, Université d'Avignon, Avignon, France, ${ }^{2}$ INRA, UMR \\ 1334 AGAP, Montpellier, France
}

Water deficit (WD) is expected to increase in intensity, frequency and duration in many parts of the world as a consequence of global change, with potential negative effects on plant gas exchange and growth. We review here the parameters that can be derived from measurements made on leaves, in the field, and that can be used to assess the effects of WD on the components of plant photosynthetic rate, including stomatal conductance, mesophyll conductance, photosynthetic capacity, light absorbance, and efficiency of absorbed light conversion into photosynthetic electron transport. We also review some of the parameters related to dissipation of excess energy and to rerouting of electron fluxes. Our focus is mainly on the techniques of gas exchange measurements and of measurements of chlorophyll a fluorescence (ChIF), either alone or combined. But we put also emphasis on some of the parameters derived from analysis of the induction phase of maximal ChIF, notably because they could be used to assess damage to photosystem II. Eventually we briefly present the non-destructive methods based on the ChIF excitation ratio method which can be used to evaluate non-destructively leaf contents in anthocyanins and flavonols.

Keywords: water deficit, photosynthesis, chlorophyll a fluorescence, leaf gas exchange, stomatal conductance, tolerance mechanisms, induction curves of maximal chlorophyll fluorescence

\section{INTRODUCTION}

Water deficit (WD) is expected to increase in intensity, frequency and duration in many parts of the world, notably in Africa, Asia and Central and South America, as a consequence of climate change (IPCC, 2014). WD is generally perceived as negative for plants basically because it can lead to stress which may in turn threaten plant survival. More commonly, WD impairs plants' photosynthetic rate and growth, thus potentially disturbing balances existing between species competing in natural habitats (Smith and Huston, 1990; Nambiar and Sands, 1993) while reducing plant productivity in cropping systems (Boyer, 1982). The latter issue has received much attention because decreases in crop productivity challenge food security (Hanjra and Qureshi, 2010). Besides, reduced production of photosynthetic products may also impair osmotic adjustment and the capacity of plants to cope with drought (Blum, 2017). Dealing with the negative effects of WD on growth and productivity will require, among others, being able to assess the way WD impacts photosynthesis, and to 
interpret plants' responses correctly within integrated views of their strategies. Of course, the issue of the impact of WD on growth and productivity is a complex one that cannot be reduced to a simple negative effect on photosynthesis, since WD may impact also developmental processes. The latter, not only the former, are involved in productivity (e.g., flowering and fruiting). Despite these limitations, leaf photosynthesis analysis remains pivotal in all WD studies. Moreover, it is quite clear that plants experience multiple stress situations in natural or field conditions, and that their responses to a combination of stresses cannot be extrapolated simply from separate studies of individual stresses (Mittler, 2006). In the case of WD there is at least the need to take into account the light conditions. Eventually, it is important not to forget that in addition to net photosynthetic $\mathrm{CO}_{2}$ assimilation per unit area and time $\left(\mathrm{A}_{\text {net }}\right)$, leaf area and distribution, as well as mitochondrial respiration are also important for growth and production. Mitochondrial respiration may not only contribute to significant carbon losses, especially under stress conditions, reducing the net carbon gain (Van Oijen et al., 2010; Sperlich et al., 2015), it is also a key regulator of the energy status of plants under stress.

$A_{\text {net }}$ is determined by stomatal conductance $\left(\mathrm{g}_{\mathrm{s}}\right)$ and mesophyll conductance $\left(\mathrm{g}_{\mathrm{m}}\right)$, which determine $\mathrm{CO}_{2}$ supply to carboxylation sites, and also by the photosynthetic metabolic potential $\left(A_{\text {pot }}\right)$, which determines the capacity of the photosynthetic machinery to process $\mathrm{CO}_{2} . \mathrm{A}_{\text {pot }}$ depends on the amount and activities of the components of the lightharvesting, the electron transport and the energy-transduction processes, as well as by the carbon metabolism components, including such enzymes as the Rubisco and processes like RUBP synthesis by the Calvin cycle (Lawlor and Cornic, 2002; Flexas et al., 2004; Chaves et al., 2009; Lawlor and Tezara, 2009). Mild WD decreases $A_{\text {net }}$ via a reduction in $\mathrm{g}_{s}$. In low light conditions, photosynthetic activity, notably electron transport and $\mathrm{NADP}^{+}$ reduction are maintained. But in high light conditions, since $A_{\text {net }}$ does not increase, an imbalance between energy capture and energy use by photochemistry occurs, leading to a decrease in the rate of linear electron transport, downregulation of ATP synthase activity, which allows to keep a high level of $\Delta \mathrm{pH}$ and of energy dissipation (Kanazawa and Kramer, 2002), and the triggering of alternative electron routes. These mechanisms may not be efficient enough to prevent the formation of reactive oxygen species (ROS) whereas scavenging mechanisms may be overflown to the point of allowing accumulation of ROS. Lawlor and Tezara (2009) hypothesized that the latter damage ATP synthase, leading to a decrease in ATP and consequently in RuBP synthesis by the Calvin cycle, and eventually Rubisco activity. In case of severe stress, damage can even lead to death (Figure 1).

This paper has not the ambition to provide a full and detailed review of the consequences of drought on photosynthesis (see Lawlor and Tezara, 2009; Pinheiro and Chaves, 2011 for instance) and on growth (Farooq et al., 2009), but to provide a review of those parameters related to photosynthesis that can be derived from measurements of gas exchange and chlorophyll $a$ fluorescence (ChlF) that are performed on leaves, in the field. Recently, a new generation of fluorimeters was made available that provide the high time resolution needed for performing measurements of fast ChlF induction kinetics. Parameters derived from analysis of the so-called OJIP transients are used to analyze the response of PSII to stress, but some of them may also be used as indicators of energy use efficiency, photoinhibition and even damage (Ripoll et al., 2016b). We shall put some emphasis on them in this review. Marginally we shall invoke also a few parameters of remote sensing which could be used in complement or as substitutes.

For readers not familiar with ChlF measurements, there are three major classes of instruments. The first class encompasses devices based on the concept of a single turnover flash (STF), the second class of instruments exploits a saturating pulse for analysis of the induction curve of maximal ChlF (i.e., the analysis of socalled OJIP transients) and the last one is designed to study steady state fluorescence for quenching analysis and for coupled ChlF and gas exchange measurements (Kalaji et al., 2014). In the first class, STF devices provide among other things information on the electron transfer reactions within PSII. Although potentially useful to characterize responses to stress, they are not commonly used in field studies and will therefore not be included in this review. For the same reason we excluded thermoluminescence (a delayed fluorescence that gives information on the occurrence of recombination reactions in PSII as a function of the redox state of the electron transport chain), as well as $77 \mathrm{~K}$ fluorescence and fast and ultra-fast fluorescence. For the reader interested in these techniques we suggest the following articles and reviews: Shinkarev (2005) for STF, Misra et al. (2001) and Ducruet and Vass (2009) for thermoluminescence, Goltsev et al. (2009) for delayed fluorescence, Srivastava and Strasser (1999) and Papageorgiou (2011) for 77 K fluorescence, and Holzwarth (2008) and Berera et al. (2009) for fast fluorescence techniques. The second class of instruments makes use of strong light pulses of few $100 \mathrm{~ms}$, to obtain information on the photosynthetic electron transport chain (ETC), its reduction kinetics, Photosystem II (PSII) antenna size and relative content of ETC components. The instruments of the last class are designed to measure ChlF intensity in the steady state, as affected by the redox state of the ETC and by changes in the ChlF yield. The analysis of the causes for yield changes is called quenching analysis. Modulated light is used as a trick to separate the effect of actinic light that drives photosynthesis and the low-intensity measuring light that is used to probe the state of the photosynthetic system on the measured ChlF intensity (Kalaji et al., 2014). Besides quenching analysis, pulsed amplitude modulated fluorimeters can be used in combination with gas exchange measurement systems to study the interactions between the ETC, the Calvin-Benson cycle, $\mathrm{CO}_{2}$ conductance and photorespiration. It is not our objective here to provide the reader with the theoretical background, the assumptions behind the models, and practical considerations of all the techniques evoked in this review. Below is a very small selection of papers and books among many readers who intend to familiarize themselves with these techniques may find useful:

(i) for gas exchange measurements (von Caemmerer and Farquhar, 1981; Nobel, 2009);

(ii) for OJIP transient measurements, performed on dark-adapted leaves (Stirbet, 2011; Kalaji et al., 2014; Goltsev et al., 2016). 


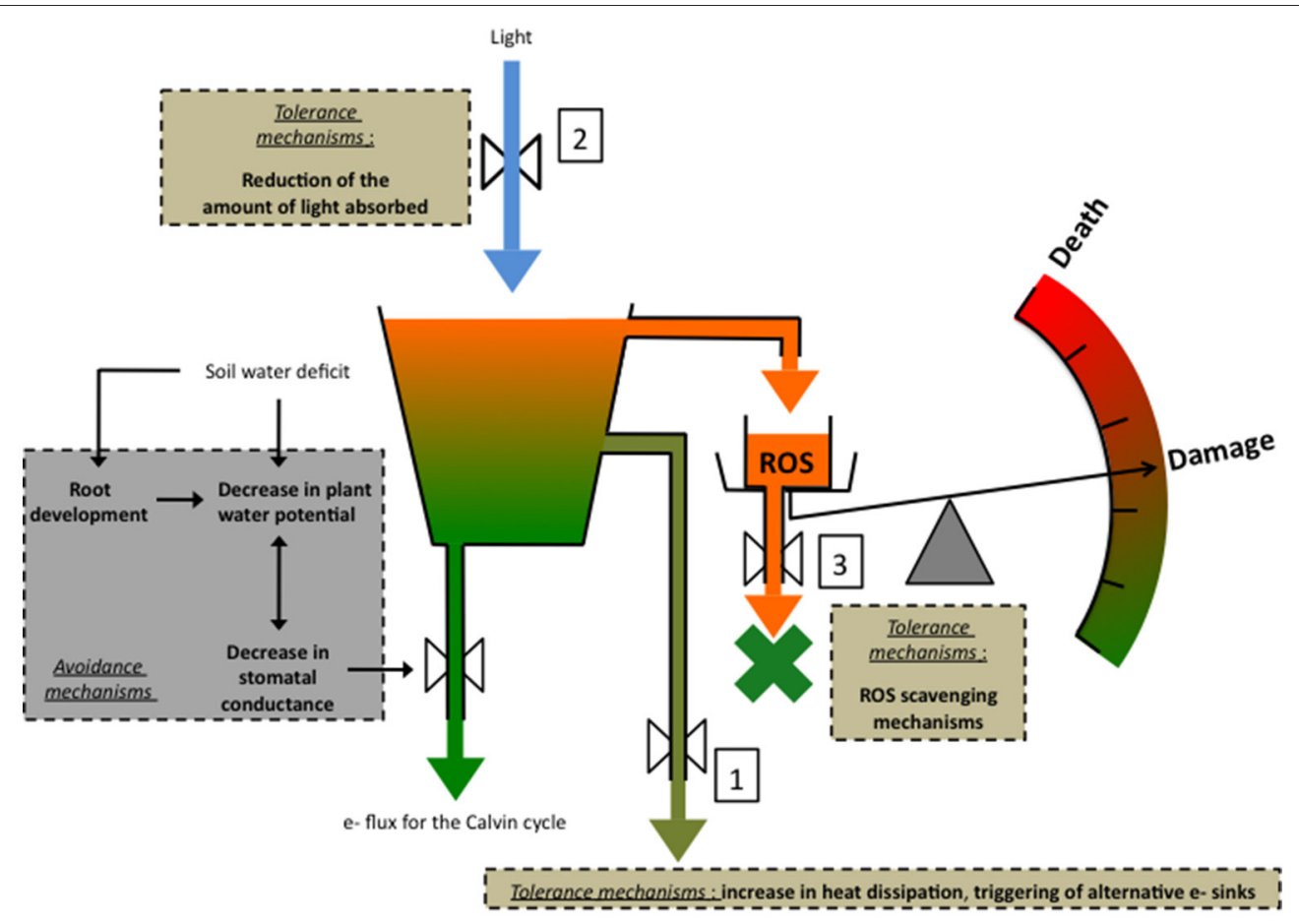

FIGURE 1 | A simplified representation of the major tolerance mechanisms against drought-associated photooxidative stress in conditions of high light. Avoidance mechanisms are also represented: (1) decreasing plant water potential $(\Psi)$ improves plant capacity to remove water from the drying soil, whereas (2) decreasing stomatal conductance $\left(g_{s}\right)$, exerts a positive effect on the plant water content by saving water. (3) root development increases plant capacity to take up water and therefore to maintain a high water content. In high light conditions, the decrease in $\mathrm{g}_{\mathrm{s}}$ entails a decrease in the quantity of $\mathrm{CO}_{2}$ entering the leaf, therefore creating an imbalance between the energy capture and energy use by photochemistry. The risk for excess energy to form potentially damaging reactive oxygen species (ROS) increases and must be mitigated by energy dissipation processes and the triggering of alternative e- sinks 1 , and by processes aiming at decreasing the quantity of light entering the leaf 2. If these mechanisms fail to prevent ROS formation, the latter can be eliminated by ROS scavenging processes 3 . In the case these mechanisms are insufficient, ROS can damage notably ATP synthase, leading to a decrease in RuBP synthesis and Rubisco activity. Eventually damage may lead to death.

(iii) for steady state fluorescence measurements under modulated light (Maxwell and Johnson, 2000; Logan et al., 2007; Murchie and Lawson, 2013; Kalaji et al., 2014).

We shall now put in perspective the parameters derived notably from measurements of leaf gas exchange and ChlF, by considering successively $g_{s}, g_{m}$, the components of photosynthetic capacity, light absorbance, efficiency of absorbed light conversion into photosynthetic electron transport, rerouting of electron fluxes and dissipation of excess energy. We shall then present the ChlF techniques that can be used to assess leaf concentrations in anthocyanins and flavonols, which may play a role as antioxidants, and eventually review the parameters that could be used to analyze photodamage. The symbols used in this review are listed in Tables 1, 2. Specific portable field measurement systems are mentioned but we have not the ambition here to provide an exhaustive list.

\section{STOMATAL CONDUCTANCE (gs)}

Whereas decreasing plant water potential and stimulating root development both result in increased water uptake, stomatal closure results in improved plant water balance and water status by acting on the other end of the water flux chain, namely by limiting transpiration losses. Stomatal functioning has been extensively studied (Damour et al., 2010) and it emerges that $\mathrm{g}_{\mathrm{s}}$ is arguably the most relevant among all indicators of WD and even plant stress in general. It is certainly one of the first parameters to be affected by WD. Plants can close stomata within minutes upon exposure to $\mathrm{WD}$, thus very efficiently preventing excessive water loss that could endanger them. Stomata represent the major point of control of water fluxes in the so-called soilplant-atmosphere continuum. Stomatal resistance to water vapor diffusion is indeed the major resistance along the pathway of water from the soil to the atmosphere. Unfortunately stomatal closure may come at a price, which is a limitation to $\mathrm{CO}_{2}$ uptake into chloroplasts, a decrease therefore in photosynthesis and growth, and consequently also an increase in the risk of photooxidative stress, i.e., the production of potentially damaging and sometimes lethal ROS. It is true that a small decrease in $\mathrm{g}_{\mathrm{s}}$ impacts transpiration more than photosynthesis (Nobel, 1999) but, in case of more severe drought or in conditions of high light, photosynthesis is inevitably reduced while the risk of photooxidative stress increases. To complete the complex picture of stomatal functioning and roles, one must be reminded that stomatal closure, by helping to maintain plant water status, 
TABLE 1 | List of symbols.

\begin{tabular}{|c|c|}
\hline$A_{\text {gross }}, A_{\text {net }}$ & Gross and net photosynthetic rate \\
\hline$A_{\max }$ & Maximal rate of net photosynthesi \\
\hline Apot & Photosynthetic metabolic potential \\
\hline ATP & Adenosine triphosphate \\
\hline CET & Cyclic electron transport \\
\hline ChlF & Chlorophyll fluorescence \\
\hline $\mathrm{C}_{\mathrm{C}}$ & $\mathrm{CO}_{2}$ concentration at the carboxylation site \\
\hline $\mathrm{C}_{\mathrm{i}}$ & Intercellular $\mathrm{CO}_{2}$ concentration \\
\hline CWSI & Crop water stress index \\
\hline ETC & Electron transport chain \\
\hline $\mathrm{F}_{\mathrm{O}}^{\prime}, \mathrm{F}_{\mathrm{m}}^{\prime}$ & Minimal and maximal values of ChIF of light-adapted leaves \\
\hline gm & Mesophyll conductance \\
\hline gs & Stomatal conductance \\
\hline $\mathrm{J}, \mathrm{J}_{\mathrm{T}}, \mathrm{ETR}$ & Electron transport rate \\
\hline$J_{A}$ & Electron transport rate for alternative sinks \\
\hline $\mathrm{J}_{\mathrm{C}}$ & Electron transport rate for carboxylation \\
\hline$J_{\circ}$ & Electron transport rate for oxygenation \\
\hline$J_{\max }$ & Light-saturated electron transport rate \\
\hline LUE & Light use efficiency \\
\hline $\mathrm{Na}$ & Leaf nitrogen content per unit leaf area \\
\hline $\mathrm{N}_{\mathrm{m}}$ & Leaf nitrogen content expressed on leaf mass basis \\
\hline $\mathrm{NADPH}$ & Nicotinamide adenosine diphosphate (reduced) \\
\hline $\mathrm{NDH}$ & NADH dehydrogenase-like \\
\hline NPQ & Non photochemical quenching \\
\hline OEC & Oxygen evolving complex \\
\hline$P C, P Q$ & Plastocyanins, Plastoquinones \\
\hline PRI & Photochemical Reflectance Index \\
\hline PSII & Photosystem ॥ \\
\hline Q & Photosynthetically active flux density \\
\hline$R_{d}$ & Rate of mitochondrial respiration in the presence of light \\
\hline$R_{n}$ & Rate of mitochondrial respiration in the absence of light \\
\hline ROS & Reactive oxygen species \\
\hline Rubisco & Ribulose 1,5-diphosphate carboxylase, oxygenase \\
\hline RuBP & Ribulose 1,5-diphosphate \\
\hline SPS & Sucrose phosphate synthase \\
\hline STF & Single turnover flash \\
\hline $\mathrm{T}_{\mathrm{a}}$ & Air temperature \\
\hline $\mathrm{T}_{\mathrm{C}}$ & Canopy temperature \\
\hline TPU & Triose-phosphate utilization \\
\hline $\mathrm{Y}_{\mathrm{NO}}$ & Quantum yield of non-light induced NPQ of ChIF \\
\hline$Y_{N P Q}$ & Quantum yield of light induced NPQ of ChIF \\
\hline$V_{c m a x}$ & Maximal carboxylation rate of Rubisco \\
\hline WD & Water deficit \\
\hline$\alpha$ & Initial quantum efficiency of PSII \\
\hline$\Phi_{\mathrm{PS} \|}$ & Efficiency of absorbed light conversion \\
\hline$\theta$ & Leaf absorbance \\
\hline$\Gamma$ & Light compensation point \\
\hline$\Gamma^{*}$ & $\mathrm{CO}_{2}$ compensation point \\
\hline$\tau$ & Specificity factor of Rubisco \\
\hline
\end{tabular}

The symbols for the so-called OJIP parameters are presented in Table 2.

mitigates the drought-associated decrease in plant water potential and therefore the capacity of plants to extract water from a dehydrating soil. It is easy to understand that the ambivalent and pivotal roles of stomata explain why stomatal functioning is such
TABLE 2 | Definition of some common OJIP/OKJIP parameters (after Strasser et co-workers), including $F_{0}, F_{m}, F_{v}$, and $F_{v} / F_{m}$.

\begin{tabular}{|c|c|}
\hline Parameter & Definition \\
\hline $\mathrm{F}_{0}$ & $\begin{array}{l}\text { Initial value of ChIF, generally taken at } 20 \text { or } \\
50 \mu \mathrm{s} \text { (O-level) }\end{array}$ \\
\hline $\mathrm{F}_{\mathrm{k}}$ & ChlF value at $300 \mu \mathrm{s}$ (K-level) \\
\hline$F_{j}$ & ChlF value at $2 \mathrm{~ms}$ (J-level) \\
\hline $\mathrm{F}_{\mathrm{i}}$ & ChIF value at $30 \mathrm{~ms}$ (I-level) \\
\hline$F_{m}$ & $\begin{array}{l}\text { Maximum value of ChIF under saturating } \\
\text { light (P-level) }\end{array}$ \\
\hline$F_{v}=F_{m}-F_{0}$ & Maximum variable ChIF \\
\hline $\mathrm{F}_{\mathrm{v}} / \mathrm{F}_{\mathrm{m}}$ & $\begin{array}{l}\text { Maximum quantum yield of primary PSII } \\
\text { chemistry }\end{array}$ \\
\hline$V_{k}=\left(F_{k}-F_{0}\right) / F_{v}$ & Relative variable ChIF at $300 \mu \mathrm{s}$ \\
\hline$V_{j}=\left(F_{j}-F_{0}\right) / F_{v}$ & Relative variable ChIF at $2 \mathrm{~ms}$ \\
\hline$v_{i}=\left(F_{i}-F_{0}\right) / F_{v}$ & Relative variable ChIF at $30 \mathrm{~ms}$ \\
\hline $\mathrm{M}_{0}=4 \mathrm{~ms}^{-1} \cdot \mathrm{v}_{\mathrm{k}}$ & $\begin{array}{l}\text { Initial slope of relative variable ChIF for } \mathrm{F}_{0} \\
\text { taken at } 50 \mu \mathrm{s}\end{array}$ \\
\hline Area & $\begin{array}{l}\text { Area between the OJIP/OKJIP curve and } \\
\text { the } \mathrm{F}_{\mathrm{m}} \text { line }\end{array}$ \\
\hline $\mathrm{S}_{\mathrm{m}}=$ Area/ $\mathrm{F}_{\mathrm{v}}$ & Normalized area \\
\hline$N=S_{m} /\left(M_{0} N_{j}\right)$ & Turnover number \\
\hline$J^{A B S}=J^{T R}+J^{D I}$ & $\begin{array}{l}\text { Rate of photon absorption by PSII antenna } \\
\text { (absorbed photon flux) }\end{array}$ \\
\hline$J_{0}^{T R}$ & $\begin{array}{l}\text { Maximum, initial rate of exciton trapping by } \\
\text { all PSII reaction centers (maximum trapped } \\
\text { exciton flux) }\end{array}$ \\
\hline JDI & $\begin{array}{l}\text { Rate of energy dissipation in PSIls by } \\
\text { processes other than trapping (dissipated } \\
\text { energy flux) }\end{array}$ \\
\hline$J_{0}^{E T 2}$ & $\begin{array}{l}\text { Electron transport flux from protein protein } \\
Q_{A} \text { to protein } Q_{B}\end{array}$ \\
\hline $\mathrm{J}_{0}^{\mathrm{RE} 1}$ & $\begin{array}{l}\text { Electron transport flux until PSI acceptors } \\
\text { (at } 30 \mathrm{~ms} \text { ) }\end{array}$ \\
\hline $\mathrm{J}^{\mathrm{ABS}} / \mathrm{RC}=\left(\mathrm{M}_{0} N_{\mathrm{j}}\right) /\left(\mathrm{F}_{\mathrm{v}} / \mathrm{F}_{\mathrm{m}}\right)$ & $\begin{array}{l}\text { Average absorbed photon flux per PSII } \\
\text { reaction centers/apparent antenna size of } \\
\text { an active PSII }\end{array}$ \\
\hline $\mathrm{J}_{0}^{\mathrm{TR}} / \mathrm{RC}=\mathrm{M}_{0} \mathrm{~N}_{\mathrm{j}}$ & Maximum trapped exciton flux per PSII \\
\hline$J D^{\prime} / R C=J A B S / R C-J_{0}^{T R} / R C$ & Dissipated energy flux per PSII \\
\hline $\begin{array}{l}\mathrm{Pl}_{\mathrm{ABS}}= \\
\left(\mathrm{RC} / \mathrm{J}^{\mathrm{ABS}}\right) \cdot\left(\mathrm{F}_{\mathrm{V}} / \mathrm{F}_{0}\right) \cdot\left(1-\mathrm{V}_{\mathrm{j}}\right) \mathrm{N}_{\mathrm{j}}\end{array}$ & $\begin{array}{l}\text { Performance index for energy conservation } \\
\text { from photons absorbed by PSII antenna to } \\
\text { the reduction of protein } Q_{B}\end{array}$ \\
\hline $\mathrm{RC} / \mathrm{J}^{\mathrm{ABS}}$ & $\begin{array}{l}\text { Contribution to the } \mathrm{Pl} \text { of the density of } \\
\text { active reaction (in the sense of } Q_{A} \\
\text { reducing) centers on a chlorophyll basis }\end{array}$ \\
\hline $\mathrm{F}_{\mathrm{v}} / \mathrm{F}_{0}$ & $\begin{array}{l}\text { Contribution to the PI of the light reactions } \\
\text { for primary photochemistry, i.e. the } \\
\text { performance due to the trapping probability }\end{array}$ \\
\hline$\left(1-V_{j}\right) N_{j}$ & $\begin{array}{l}\text { Contribution to the PI of the dark reactions, } \\
\text { or, in other words, the performance due to } \\
\text { the conversion of excitation energy to } \\
\text { photosynthetic electron transport }\end{array}$ \\
\hline $\mathrm{PI}_{\mathrm{ABS}}^{\mathrm{TOT}}=\mathrm{PI}_{\mathrm{ABS}} \cdot\left(1-\mathrm{V}_{\mathrm{i}}\right) /\left(\mathrm{V}_{\mathrm{i}}-\mathrm{V}_{\mathrm{i}}\right)$ & $\begin{array}{l}\text { Performance index for energy conservation } \\
\text { from photons absorbed by PSII antenna } \\
\text { until the reduction of PSI acceptors }\end{array}$ \\
\hline
\end{tabular}

a highly integrated and regulated process in plants (Damour et al., 2010).

Leaf $g_{s}$ is commonly measured in the field using portable gas exchange measurement systems (Table 3). The latter are designed 
TABLE 3 | Brief overview of the major types of portable devices commonly used for field measurements of photosynthesis-related parameters.

\begin{tabular}{|c|c|c|}
\hline Type of instrument & Nature of measurements & Typical parameters \\
\hline $\begin{array}{l}\text { Portable leaf gas exchange measurement } \\
\text { systems }\end{array}$ & $\begin{array}{l}\text { Steady state gas exchanges under controlled } \\
\text { conditions } \\
\text { A-C } C_{i} \text { response curves } \\
\text { A-Q curves }\end{array}$ & 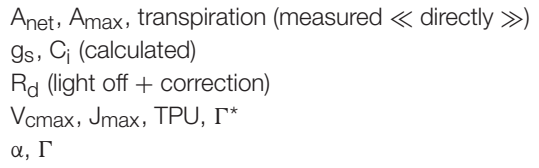 \\
\hline Modulated fluorimeter & ChIF & $\begin{array}{l}F_{\mathrm{v}} / F_{m}, F_{O} \text { (on dark-adapted leaves) } \\
F_{v}^{\prime} / F_{m}^{\prime}, \Phi_{P S I I} \text { (on light-adapted leaves) } \\
\text { NPQ, qP (quenching analysis) } \\
J_{\max }, \alpha\left(\Phi_{P S I I}-Q \text { curves) }\right.\end{array}$ \\
\hline $\begin{array}{l}\text { Coupled leaf gas exchange and modulated } \\
\text { ChIF measurement systems }\end{array}$ & $\begin{array}{l}\text { Steady state gas exchanges under controlled } \\
\text { conditions + ChIF }\end{array}$ & $\begin{array}{l}\text { In addition to all the above-mentioned parameters: } \\
\text { gm, photorespiration and alternative routes for e- } \\
\text { flow }\end{array}$ \\
\hline $\begin{array}{l}\text { Modulated fluorimeter + dual wavelengths } \\
\text { absorbance spectrometer }\end{array}$ & ChIF + P700 absorption & $\begin{array}{l}\text { Cyclic electron transport activity in addition to the } \\
\text { usual parameters }\end{array}$ \\
\hline Non modulated, high time resolution fluorimeter & Fast ChIF induction kinetics & $\begin{array}{l}\mathrm{F}_{\mathrm{v}} / \mathrm{F}_{\mathrm{m}}, \mathrm{F}_{\mathrm{O}} \\
\text { So-called OJIP parameters (Table 2) }\end{array}$ \\
\hline $\begin{array}{l}\text { Modulated fluorimeter based on the excitation } \\
\text { ratio method }\end{array}$ & ChIF at different excitation wavelengths & [anthocyanins], [flavonols] \\
\hline Chlorophyll meter & Leaf transmittance & $\theta$ \\
\hline
\end{tabular}

for concomitant measurements of net exchange of $\mathrm{CO}_{2}$ in a large range of photosynthetically active flux density (Q), $\mathrm{CO}_{2}$ concentration of the air, temperature and humidity. Portable gas exchange measurement systems include the CIRAS-3 (PP systems, Amesbury, USA), the GFS-3000 (Walz Gmbh, Effeltrich, Germany), the LI-6400 and LI-6800 (LI-COR ${ }^{\circledR}$, Lincoln, USA) and the iFL (Opti-sciences, Hudson, USA).

Leaf (or canopy) temperature can be measured as an alternative to stomatal conductance as an indicator of WD (Jackson et al., 1981). The idea is that when stomata close, the cooling effect associated with transpiration is reduced, resulting in an increase in leaf or canopy temperature. Leaf or canopy surface temperatures can be measured easily through infrared thermography. The measured temperatures can then be exploited to calculate parameters such as the Leaf Temperature Difference which corresponds to the difference in leaf temperature under water-deficit and well-watered conditions. The Crop Water Stress Index of Idso et al. (1981) and Jackson et al. (1981) is defined as the difference between air and canopy temperature $\left(T_{a}\right.$ and $\mathrm{T}_{\mathrm{c}}$, respectively), normalized for the evaporative demand as determined by means of a lower limit LL (the case of a canopy transpiring at its potential rate) and an upper limit UL (a nontranspiring canopy):

$$
\begin{aligned}
\text { CWSI }= & {\left[\left(\mathrm{T}_{\mathrm{c}}-\mathrm{T}_{\mathrm{a}}\right)-\left(\mathrm{T}_{\mathrm{c}}-\mathrm{T}_{\mathrm{a}}\right)_{L L}\right] /\left[\left(\mathrm{T}_{\mathrm{c}}-\mathrm{T}_{\mathrm{a}}\right)_{\mathrm{UL}}\right.} \\
& \left.-\left(\mathrm{T}_{\mathrm{c}}-\mathrm{T}_{\mathrm{a}}\right)_{\mathrm{LL}}\right]
\end{aligned}
$$

The CWSI has to be calculated under clear sky conditions. It proved capable of predicting stress in plants 1-2 days before visual detection (Kacira et al., 2002). There are several methodological difficulties associated with the CWSI, including a high sensitivity to windy conditions. Other available indexes are the Temperature-Vegetation Dryness Index of Sandholt et al. (2002) or the Temperature Vegetation Index of Prihodko and Goward (1997). Generally, it can be said that, despite the progress of techniques and concepts, all these real-time, model-based indexes, for all the advantages they provide, are still lacking accuracy and require careful parameterization.

\section{MESOPHYLL CONDUCTANCE $\left(\mathrm{g}_{\mathrm{m}}\right)$}

Mesophyll conductance determines $\mathrm{CO}_{2}$ supply from substomatal cavities to carboxylation sites. $g_{m}$ has anatomical and physical characteristics, including $\mathrm{CO}_{2}$ solubility, the distribution of chloroplasts, the surface of chloroplasts exposed to the intercellular air space, surface area of intercellular spaces, walls and cytosol, and dimensions of the intercellular spaces which change as tissues and cells shrink with WD (Lawlor and Tezara, 2009; Tomas et al., 2013). The conductance through the liquid phase is generally believed to be the most limiting factor for $\mathrm{CO}_{2}$ diffusion in the mesophyll for many species (Flexas et al., 2012). $g_{m}$ can change rapidly and independently of leaf anatomy, for instance it can decrease as a consequence of soil WD (Warren, 2008), supporting the view that $g_{m}$ is also biochemical in nature. $\mathrm{g}_{\mathrm{m}}$ depends on carbonic anhydrase activity, which facilitates $\mathrm{CO}_{2}$ transfer to Rubisco active sites, and has a metabolic component associated with aquaporins, which may act as $\mathrm{CO}_{2}$ channels (Mori et al., 2014). Of course, $g_{m}$ can also decrease as a long-term response to WD (Gu et al., 2012; Han et al., 2016).

For years the importance of $g_{m}$ has been underestimated in ecological and agronomical studies. Nowadays the quantitative importance of $\mathrm{g}_{\mathrm{m}}$ in the control of photosynthesis has been 
well established but there are still ongoing controversies about estimation techniques. $\mathrm{g}_{\mathrm{m}}$ can be estimated from joint measurements of gas exchange and chlorophyll fluorescence (Table 3), a common feature of the portable systems available on the market, using the constant electron transport rate $(\mathrm{J})$ method (Bongi and Loreto, 1989; Harley et al., 1992), or the variable J method (Di Marco et al., 1990; Harley et al., 1992). gm can also be estimated by the carbon isotope method (Evans et al., 1986; von Caemmerer and Evans, 1991; von Caemmerer et al., 2014), and by the so-called $\mathrm{A}-\mathrm{C}_{\mathrm{i}}$ curves fitting methods (Dubois et al., 2007; Sun et al., 2014; Sharkey, 2016). Important methodological difficulties are associated with evaluations of $g_{m}$ (for a review see notably Warren and Dreyer, 2006; Pons et al., 2009; Tholen et al., 2012). There are all the more important that some assumptions associated with $g_{m}$ estimation in current $A-C_{i}$ curve-fitting methods introduce biases in fitting other model parameters. In spite of these difficulties and of debates (Warren, 2006; Warren and Dreyer, 2006; Lawlor and Tezara, 2009; Buckley and Warren, 2014), $g_{m}$ has been going on fuelling a lot of interest among researchers during the last decade. Recently, MoualeuNgangue et al. (2017) presented a new method to fit $A-C_{i}$ and $\Phi_{\text {PSII }}-C_{i}$ curves simultaneously. $\Phi_{\text {PSII }}$ represents the quantum efficiency of photosystem II (PSII) in $\mu \mathrm{mol}$ electrons $/ \mu \mathrm{mol}$ photons absorbed by PSII (Genty et al., 1989; Bilger et al., 1995). The newly described method of Moualeu-Ngangue et al. (2017), using the multiple phase flash approach for $\Phi_{\text {PSII }}$ (Loriaux et al., 2013), allows the estimation of the $g_{m}$ dependence on $C_{i}$.

\section{METABOLIC vs. DIFFUSIONAL LIMITATIONS TO A $_{\text {net }}$-EVALUATION OF PHOTOSYNTHETIC CAPACITY}

A decrease in $A_{\text {net }}$ must not systematically be interpreted as a consequence of a drought-associated decrease in diffusional limitations of $\mathrm{CO}_{2}$ supply to carboxylation sites, i.e., a decrease in $\mathrm{g}_{\mathrm{s}}$ or in the anatomical and physical components of $\mathrm{g}_{\mathrm{m}}$. Indeed, $\mathrm{A}_{\text {net }}$ may also decrease as a consequence of metabolic limitations. An easy method to test the hypothesis of $A_{\text {net }}$ limitation not associated to reduction in $\mathrm{CO}_{2}$ diffusion consists in using a high concentration of $\mathrm{CO}_{2}$ (Lawlor and Cornic, 2002). If the droughtassociated decrease in $\mathrm{A}_{\text {net }}$ persists in such conditions, this will be considered as proof for the existence of non-diffusive limitations of photosynthesis. One common way of addressing this issue consists in measuring the maximal rate of net photosynthesis in conditions of non-limiting light and $\mathrm{CO}_{2}\left(\mathrm{~A}_{\max }\right)$. A non-diffusive decrease in $A_{\max }$ can generally be attributed to a decrease in one or more of the major components of photosynthetic capacity, namely $\mathrm{V}_{\mathrm{cmax}}, \mathrm{J}_{\max }$ and TPU (Figure 2), the maximum carboxylation rate, the light-saturated rate of electron transport and triose-phosphate utilization, respectively (Farquhar et al., 1980, 2001; Harley P. C. et al., 1992). $\mathrm{V}_{\mathrm{cmax}}$ is related to Rubisco amount and activity, $\mathrm{J}_{\max }$ represents the limitation to photosynthesis imposed by RuBP regeneration capacity, and TPU the limitation to photosynthesis imposed by triose-P utilization for starch and sucrose synthesis (Sharkey et al., 1986; Yang et al., 2016). The impact of WD on the amount and

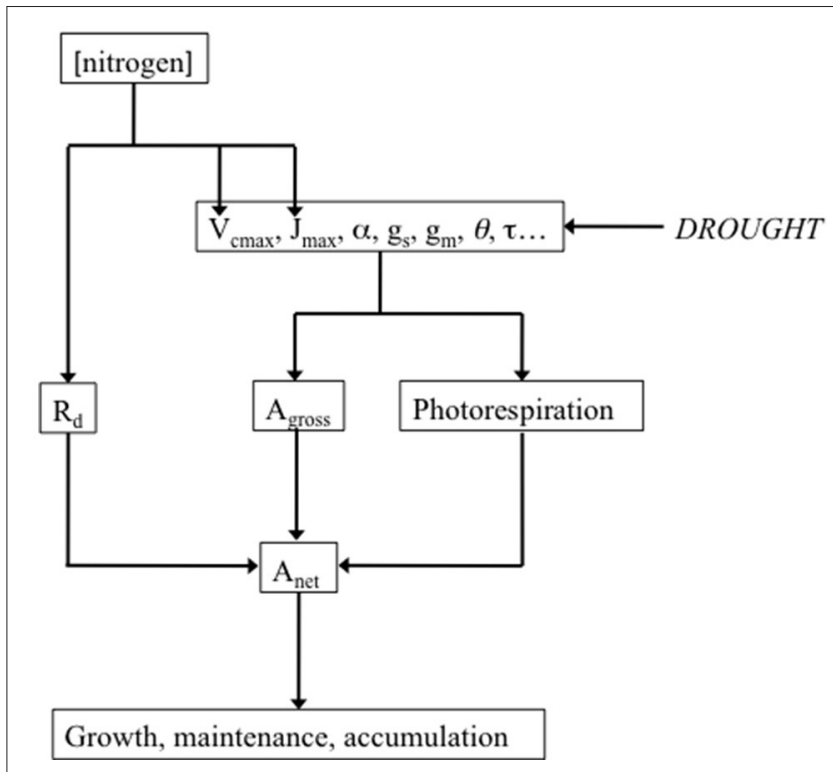

FIGURE 2 | Drought potential impact on the major parameters of the biochemical model of leaf photosynthesis, and their link with net photosynthesis $\left(A_{\text {net }}\right)$. Drought potentially decreases the maximum carboxylation rate $\left(V_{c m a x}\right)$, the light-saturated rate of electron transport ( $\left.J_{\max }\right)$, the quantum efficiency of photosystem II $(\alpha)$, stomatal conductance to $\mathrm{CO}_{2}$ $\left(g_{s}\right)$, mesophyll conductance $(\mathrm{gm})$, leaf absorbance $(\theta)$, the specificity factor of Rubisco $(\tau)$. All these parameters determine gross photosynthesis (Agross) and photorespiration, which, in addition to mitochondrial respiration $\left(R_{d}\right)$, in turn determine $A_{\text {net }}$. Measuring and analyzing all these parameters can help understanding how drought impacts growth through $A_{\text {net. }}$. The influence of nitrogen on the determinants of photosynthetic capacity was represented as a reminder. Leaf nitrogen content expressed either on a leaf area $\left(\mathrm{N}_{\mathrm{a}}\right)$ or on a dry matter $\left(\mathrm{N}_{\mathrm{m}}\right)$ basis is generally well correlated with photosynthetic capacity (Field and Mooney, 1983; Evans, 1989; Kellomäki and Wang, 1997; Walcroft et al., 1997; Urban et al., 2003; Urban and Léchaudel, 2005; Kattge et al., 2009).

activity of Rubisco has been studied extensively. For Parry et al. (2002) drought can result can result in Rubisco deactivation. Lawlor and Tezara (2009) found that Rubisco activity is not very well correlated to decreases in $A_{\text {net }}$. They consider that only severe WD can impact the content in Rubisco whereas Rubisco activity relates mainly on ATP status. There are numerous studies showing the impact of drought on $\mathrm{J}_{\max }$. For instance, MartinStPaul et al. (2012), studying three population of Quercus ilex in different sites, observed steeper declines of $\mathrm{J}_{\max }$ as predawn leaf water potential declined in the wettest site compared with the drier sites (Flexas et al., 2004). discussed the impact of WD on sucrose phosphate synthase (SPS). SPS activity decreases as $g_{s}$ decreases and would translate into a decrease in TPU. Damour et al. (2008) observed that photosynthetic capacity of leaves of lychee trees submitted to long-term drought decreases reversibly as a consequence reduced growth, sink activity, translocation and phloem loading.

$\mathrm{V}_{\mathrm{cmax}}, \mathrm{J}_{\max }$ and TPU are commonly calculated using the A- $C_{i}$ curves (Table 3; von Caemmerer and Farquhar, 1981; Sharkey et al., 2007). Several assumptions behind the model underlying the $\mathrm{A}-\mathrm{C}_{\mathrm{i}}$ curves technique have been questioned and 
optimizing fits has been an important objective for the last years (Ethier and Livingston, 2004; Dubois et al., 2007; Sharkey et al., 2007; Gu et al., 2014; Duursma, 2015; Bellasio et al., 2016; Moualeu-Ngangue et al., 2017). Recently, Buckley and DiazEspejo (2015) stressed that there are methodological difficulties associated with J-Q submodels of photosynthesis, which result in underestimating $J_{\max }$ values. Alternative methods consist in exploiting light response curves or in incorporating the J-Q submodel directly into the photosynthesis model during the fitting process. Also, obtaining $\mathrm{A}-\mathrm{C}_{\mathrm{i}}$ curves is a time-consuming process because the leaf and gas exchange system is allowed to reach a steady state at each new applied $\left[\mathrm{CO}_{2}\right]$. Following ideas of Davis et al. (1987) and observations of McDermitt et al. (1989), Laisk and Oja (1998), and Stinziano et al. (2017) developed a novel $\mathrm{A}-\mathrm{C}_{\mathrm{i}}$ response technique, utilizing non-steady state measurements of gas exchange. Exploiting the capacity of the latest leaf gas exchange measurements systems to provide rapid control and measurement of step-wise changes in reference and sample $\left[\mathrm{CO}_{2}\right]$, they showed that it is possible to reduce to less than 5 min the time necessary to determine $A-C_{i}$ responses.

In addition to the $\mathrm{A}-\mathrm{C}_{\mathrm{i}}$ curve method, $\mathrm{J}_{\max }$ can be calculated from measurements of ChlF following Smith (1937) and Harley P. C. et al. (1992). Urban et al. (2008) proposed to derive the initial quantum efficiency of PSII $(\alpha)$ and $J_{\max }$ from $\Phi_{\mathrm{PSII}^{-}}$ $\mathrm{Q}$ curves (Table 3). So far, ChlF parameters derived from the analysis of OJIP/OKJIP transients have not been exploited to estimate photosynthetic capacity, and more specifically $\mathrm{J}_{\max }$. In that prospect, it would certainly be interesting to evaluate the total number of electrons transferred into the photosynthetic electron transport chain $(\mathrm{N})$, assuming that there is a strict proportionality between $\mathrm{N}$ and $\mathrm{S}_{\mathrm{m}}$ (Stirbet, 2011), where $\mathrm{S}_{\mathrm{m}}$ represents the normalized area of the ChlF induction curve. The high time resolution fluorimeters that can be purchased are either associated to portable leaf gas exchange measurement systems, like in the LI-6800, as stand-alone non modulated devices (like the Pocket PEA and the Handy PEA of Hansatech), or as standalone modulated devices such as the PAM-2500 of Walz or the PAR-FluorPEN FP 100-MAX of Photon Systems Instruments.

\section{LIGHT ABSORPTION BY LEAVES}

Theoretically the capacity of the photosynthetic machinery to process $\mathrm{CO}_{2}$ is determined firstly by its capacity to capture light and to use absorbed energy by PSII ( $\left.{ }^{\mathrm{ABS}}\right)$.

$$
\mathrm{J}^{\mathrm{ABS}}=\mathrm{Q}^{*} \theta^{*} 0.5
$$

where $\mathrm{J}^{\mathrm{ABS}}$ represents the rate of photon absorption by PSII antennae, Q the incident photosynthetically active quantum flux in $\mu$ mol photons $\mathrm{m}^{-2} \mathrm{~s}^{-1}$ and $\theta$ the leaf absorbance. It is generally accepted that $50 \%$ of Q is absorbed by PSII and $50 \%$ by PSI. Massantini et al. (1990) observed a decrease in $\theta$ of waterstressed Amaranthus leaves. A decrease in $\theta$ would indeed help leaves to better cope with WD by reducing the amount of energy absorbed by photosystems and therefore the associated risk of photooxidative stress. There are few references about the effect of WD on $\theta$ and all of them are not confirming that WD results in a substantial decrease in $\theta$ (Osuna et al., 2015).

$\theta$ may be estimated from the formula: 1-absorbance of red light/absorbance of near infra-red light. Alternatively, $\theta$ can be evaluated exploiting correlations with leaf chlorophyll content (Table 3; Bauerle et al., 2004; Urban et al., 2008). One of the most popular instruments is the Chlorophyll meter SPAD $502^{\circledR}$ (Konica/Minolta, Osaka, Japan), which estimates leaf chlorophyll content based on the ratio of leaf transmittance between a chlorophyll non-absorbing wavelength and an absorbing one. Two other chlorophyll meters provide similarly precise and accurate measurements with different wavelength ratios. CCM-200 ${ }^{\circledR}$ from Opti-Sciences Inc. (Hudson, USA) uses an equivalent transmittance ratio $(653$ and $931 \mathrm{~nm})$ and Dualex $4^{\circledR}$ from Force-A (Orsay, France) uses a ChlF ratio (excited at 375 and $650 \mathrm{~nm}$ ) (Cerovic et al., 2012). At sub-meter scale, an average chlorophyll content can also be estimated using the FIELDSCOUT CM-1000 ${ }^{\circledR}$ (Spectrum Technologies Inc., Plainfield, USA).

Leaf light avoidance movements probably play an important role in light absorption reduction, notably in the short term. They could be monitored using imaging techniques. Clearly there is ample room for future developments in that direction.

\section{EFFICIENCY OF LIGHT CONVERSION INTO PHOTOSYNTHETIC ELECTRON TRANSPORT-PHOTOINHIBITION}

The efficiency of absorbed light conversion, $\Phi_{\text {PSII }}$, determines, in addition to the amount of absorbed light, $\mathrm{J}^{\mathrm{ABS}}$, the photosynthetic electron flux, $\mathrm{J}_{\mathrm{T}}$ (alias J or ETR).

$$
\begin{gathered}
\mathrm{J}_{\mathrm{T}}=\Phi_{\mathrm{PSII}}{ }^{*} \mathrm{~J}^{\mathrm{ABS}} \\
\Phi_{\mathrm{PSII}}=\mathrm{F}_{\mathrm{v}}^{\prime} / \mathrm{F}_{\mathrm{m}}^{\prime}{ }^{*} \mathrm{qP}
\end{gathered}
$$

where $\mathrm{F}_{\mathrm{v}}^{\prime} / \mathrm{F}_{\mathrm{m}}^{\prime}$ represents the quantum efficiency of so-called "open" (oxidized) PSII reaction centers and qp, photochemical quenching, the proportion of open PSII centers (Schreiber et al., 1986; Maxwell and Johnson, 2000).

$$
\mathrm{F}_{\mathrm{v}}^{\prime}=\mathrm{F}_{\mathrm{m}}^{\prime}-\mathrm{F}_{0}^{\prime}
$$

where $\mathrm{F}_{\mathrm{m}}^{\prime}$ and $\mathrm{F}_{0}^{\prime}$ represent the maximum value of ChlF under saturating illumination and the minimal ChlF, respectively, of light-adapted leaves.

$\mathrm{F}_{\mathrm{v}}^{\prime} / \mathrm{F}_{\mathrm{m}}^{\prime}$ is correlated with the maximum quantum yield of primary PSII photochemistry, $\mathrm{F}_{\mathrm{v}} / \mathrm{F}_{\mathrm{m}}$, and with $\alpha$ (Urban and Alphonsout, 2007).

$$
\mathrm{F}_{\mathrm{v}}=\mathrm{F}_{\mathrm{m}}-\mathrm{F}_{0}
$$

where $\mathrm{F}_{\mathrm{m}}$ represents the maximum value of ChlF under saturating illumination, and $\mathrm{F}_{0}$, the initial (minimal) value of chlorophyll fluorescence, the level of fluorescence emission when all the primary quinone acceptors $\left(\mathrm{Q}_{\mathrm{A}}\right)$ are in the oxidized state, which is generally measured on dark adapted samples (Björkman 
and Demmig, 1987; Maxwell and Johnson, 2000; Roháçek, 2002). From a theoretical point of view, it is important to be aware that one of the major assumptions behind the interpretation of the fluorescence rise from minimal to maximal ChlF, including OJIP transients analysis, is that variable fluorescence is determined by the redox state of $\mathrm{Q}_{\mathrm{A}}$, the first quinone acceptor of PSII, as originally proposed by Duysens and Sweers (1963). See Schansker et al. (2014) for a discussion about this hypothesis. From a practical point of view what is important is to ensure that both minimal and maximal ChlF are correctly measured. This is also true for OJIP transient analysis since they depend on normalizations that are very sensitive to the accuracy of the determination of $F_{0}$ and $F_{m}$ values (Kalaji et al., 2014). For useful considerations about dark adaptation, particularly in field trials (see also Kalaji et al., 2014).

The $\mathrm{F}_{\mathrm{v}} / \mathrm{F}_{\mathrm{m}}$ values average approximatively $0.83-0.84$ in most C3 plants (Björkman and Demmig, 1987; Pfündel, 1998). Even though $\mathrm{F}_{\mathrm{v}} / \mathrm{F}_{\mathrm{m}}$ is arguably one of the most commonly used parameters derived from measurements of ChlF to assess plant stress, notably photoinhibition, i.e., photosynthesis reduction by excess of light, it remains generally unaffected by moderate drought (Genty et al., 1987; Tezara et al., 1999; Christen et al., 2007; Oukarroum et al., 2007). More severe WD may decrease $\mathrm{F}_{\mathrm{v}} / \mathrm{F}_{\mathrm{m}}$ values but, while substantial decreases in $\mathrm{F}_{\mathrm{v}} / \mathrm{F}_{\mathrm{m}}$ are indeed indicators of photo-damage, small decreases can be interpreted in terms of photo-protection (Adams et al., 2006). Similarly, a relatively moderate $\mathrm{F}_{\mathrm{v}}^{\prime} / \mathrm{F}_{\mathrm{m}}^{\prime}$-associated decrease in $\Phi_{\mathrm{PSII}}$ may be interpreted as reduced risk of photo-oxidative stress. Even damage to D1 protein under WD, which indeed translates into lower values of $\mathrm{q}_{\mathrm{P}}$ and $\mathrm{F}_{\mathrm{v}} / \mathrm{F}_{\mathrm{m}}$ (Giardi et al., 1996), can be seen as "positive photo-inhibition" since damaged D1 proteins are rapidly degraded and replaced.

In addition to the fluorimeters build in most recent portable gaz exchange measurement systems, the user can use dedicated modulated fluorimeter such as the FMS2 by Hansatech instruments (King's Lynn, UK), the Mini-PAM II by Walz, the OS5+ by Opti-Sciences, or the FluorPen FP 100-MAX of Photo Systems Instruments (Drasov, Czech Republic).

\section{REROUTING OF ELECTRON FLUXES (FIGURE 3)}

Light reactions of photosynthesis convert the solar energy flux into chemical energy in the form of NADPH and ATP, which are needed for $\mathrm{CO}_{2}$ assimilation. In the case of drought, the photosynthetic electron transport rate can be reallocated from photosynthesis to photorespiration (Noctor et al., 2002; Galmès et al., 2007). In cotton it was observed that photorespiration increases as a consequence of drought (Cornic and Fresneau, 2002; Ennahli and Earl, 2005; Massacci et al., 2008; Chastain et al., 2014) but decreases have also been observed (Zhang et al., 2011). The glycolate oxidase and the Mehler peroxidase reactions respectively lead to the production of substantial amounts of $\mathrm{H}_{2} \mathrm{O}_{2}$ (a lesser evil than ${ }^{1} \mathrm{O}_{2}$ and $\mathrm{O}_{2}^{-}$), either in peroxisomes or chloroplasts (Smirnoff, 1993; Noctor et al., 2002). Catalase, alongside several other enzymes and enzymatic systems, will then eliminate $\mathrm{H}_{2} \mathrm{O}_{2}$.
See Busch (2013) for a review of the existing methods for evaluating photorespiration. Both $\mathrm{J}_{\mathrm{C}}$ and $\mathrm{J}_{\mathrm{O}}$, the electron fluxes for carboxylation and for oxygenation, respectively, can be calculated using concomitant measurements of $\mathrm{A}_{\text {net }}$ and $\Phi_{\mathrm{PSII}}$, using portable gas exchange + ChlF measurement systems, followed by measurements of $\mathrm{R}_{\mathrm{d}}$ (Valentini et al., 1995). Prior calibration of $\Phi_{\text {PSII }}$ at $1-2 \% \mathrm{O}_{2}$ must however be done (Genty et al., 1989). It is also in theory required to determine $R_{d}$, the rate of mitochondrial respiration in light, and $\theta$. The calibration procedure is time-consuming but can then be exploited to effect routine measurements on adequate plant material. The procedure can also be exploited to evaluate the electron flow to so-called alternative sinks, $\mathrm{J}_{\mathrm{A}}$ (see Urban et al., 2008 for an example of field application of these methods). $R_{d}$ plays a key-role in the photosynthetic carbon metabolism of leaves experiencing WD (Atkin and Macherel, 2009; Lawlor and Tezara, 2009), and also because it is an essential component of many models $\left(\mathrm{J}_{\mathrm{C}}, \mathrm{J}_{\mathrm{O}}\right.$, $\left.\mathrm{J}_{\mathrm{A}}, \mathrm{g}_{\mathrm{m}}, \tau \ldots\right)$. By suppressing the light source, after equilibration, it is possible to easily measure $R_{n}$, the rate of mitochondrial respiration in the absence of light. $R_{n}$ is not equal to $R_{d}$. There are however techniques to derive $R_{d}$ from $R_{n}$ following the methods of Kok (1948) or Laisk (1977). The latter has been widely exploited (Brooks and Farquhar, 1985; von Caemmerer et al., 1994; Peisker and Apel, 2001; Priault et al., 2006; Flexas et al., 2007; Urban et al., 2008). A method based on simultaneous measurements of ChlF and gas exchange (see below) has been proposed by Yin et al. (2009) and evaluated Yin et al. (2011). This method is valid for both $\mathrm{C}_{3}$ and $\mathrm{C}_{4}$ plants. More recently, the new method of Moualeu-Ngangue et al. (2017) which replaces $g_{m}$ by the fraction of incoming photosynthetic photons harvested by PSII, was found to improve estimation of all major parameters derived from $A-C_{i}$ curves analysis, including $R_{d}$.

In oxygenic photosynthesis, the production ratio of ATP/NADPH by linear electron transport is about 1.29 whereas the ratio required by the Calvin cycle is 1.5 (Allen, 2002). In $C_{3}$ plants, photorespiration increases the ratio up to 1.67 (Shikanai and Yamamoto, 2017). To satisfy the ATP/NADPH production ratio, supplementary mechanisms for ATP synthesis are needed. In cyclic electron transport (CET), electrons are transferred from ferredoxin to the plastoquinone pool, generating a trans-thylakoid $\mathrm{H}^{+}$gradient via the $\mathrm{Q}$ cycle of Cyt $b_{6} f$ complex, without net production of NADPH (Yamori and Shikanai, 2016). The trans-thylakoid $\mathrm{H}^{+}$gradient $(\Delta \mathrm{pH})$ is a major component of the proton motive force that contributes to ATP synthesis. The $\Delta \mathrm{pH}$ also down-regulates photosynthetic electron transport by downregulating Cyt $b_{6} f$ complex activity and by evacuating absorbed light energy in excess under the form of heat from PSII antennae (Shikanai and Yamamoto, 2017). Apart from adjusting the ATP/NADPH ratio, the cyclic electron transfert (CET) participates in the development of non-photochemical quenching, NPQ (Niyogi, 2000), therefore affording protection against photooxidative stress (Martin et al., 2004). Besides, electrons from PSI which do not follow the linear electron transport route or the CET route are transferred to $\mathrm{O}_{2}$ to generate superoxide and other reactive oxygen species (ROS) that are normally scavenged by the water-water cycle. The water-water cycle consumes also reducing equivalents generated by PSI, ferredoxin, and NADPH. Besides the water-water cycle, 


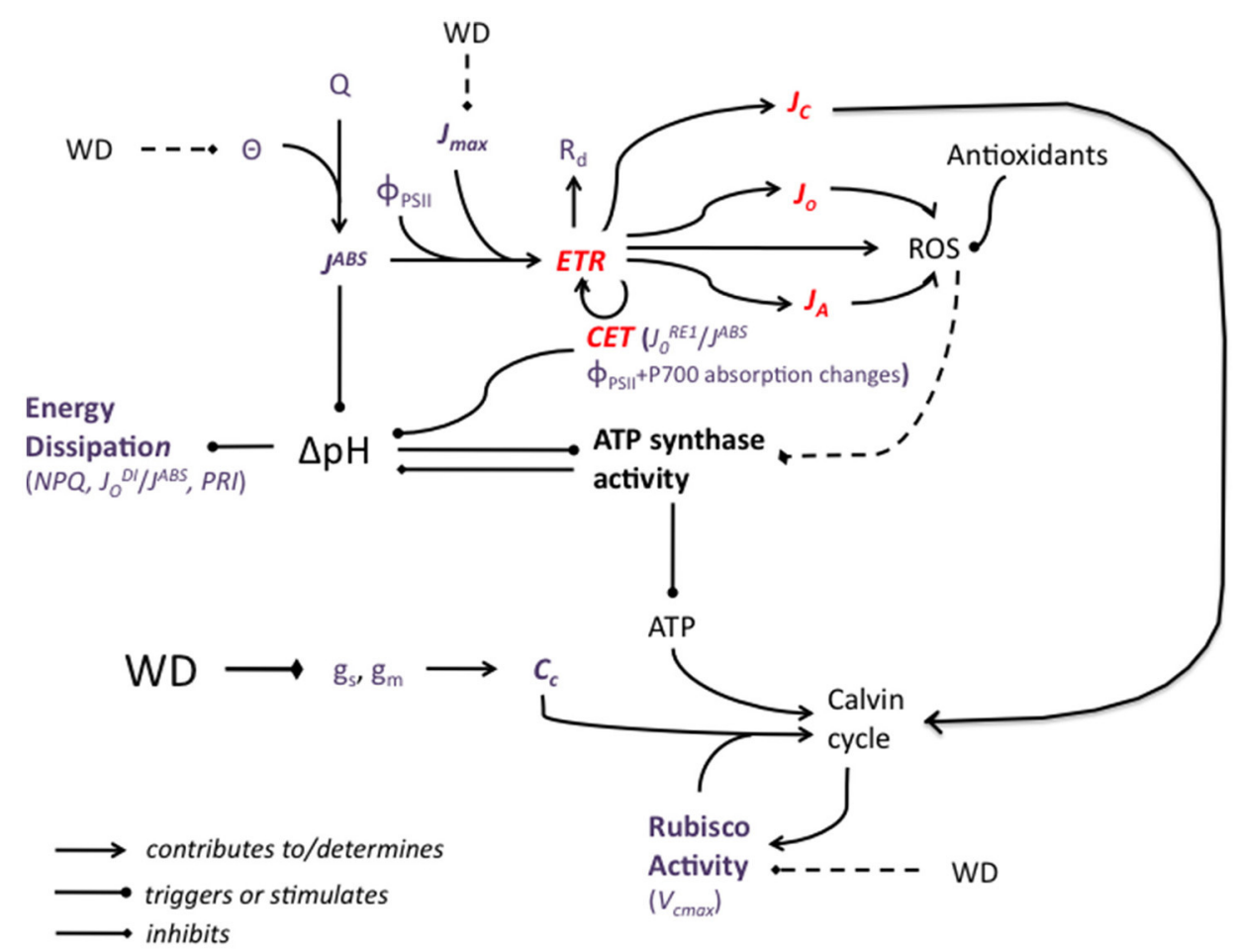

FIGURE 3 | A simplified representation of the potential impact of water deficit (WD) on the major components of the photosynthetic machinery. WD decreases stomatal and mesophyll conductance, $\mathrm{g}_{\mathrm{s}}$ and $\mathrm{gm}_{\mathrm{m}}$, leading to a decrease in the $\mathrm{CO}_{2}$ concentration at the carboxylation sites, $\mathrm{C}_{\mathrm{C}}$. In conditions of high light, the slowing down of the Calvin cycle creates an energy imbalance and electron fluxes (ETR: electron transport rate) are rerouted from NADP ${ }^{+}$reduction to photorespiration, to alternative electron sinks, to mitochondrial respiration, $R_{d}$, and to the cyclic electron transport (CET). $J_{C}$, J $J_{O}$, and $J_{A}$ are the electron fluxes for carboxylation, oxygenation and alternative sinks, respectively. CET activity can be evaluated by measuring both $\Phi_{\mathrm{PS}}$ and P700- dependent absorption changes at $820 \mathrm{~nm}$ relative to $870 \mathrm{~nm}$. J $\mathrm{R}_{0}^{\mathrm{RE}} / \mathrm{JABS}$ could also be used as an indicator of CET activity. Reactive oxygen species (ROS) may also be synthetized and they are not necessarily fully eliminated by ROS-scavenging molecules and processes. ROS have been hypothesized to damage ATP synthase, decreasing ATP production, which contributes again to slowing down the Calvin cycle. WD may impact negatively Rubisco activity (as assessed by the maximal carboxylation rate, $V_{c m a x}$ ) but a WD-associated decrease in $V_{c m a x}$ is more likely a consequence than a cause of the slowing down of the Calvin Cycle. Besides high light ( $Q$ ) conditions, the cyclic electron transfert (CET), contributes to the trans-thylakoid $\mathrm{H}^{+}$gradient, $\Delta \mathrm{pH}$, which drives ATP synthesis. ATP synthesis, by consuming protons, acts in the opposite direction. High $\Delta \mathrm{pH}$ triggers excess absorbed energy (JABS) dissipation processes, which can be evaluated by measuring non-photochemical quenching (NPQ), the ratio of dissipated on absorbed energy fluxes, $\mathrm{J}_{\mathrm{O}}^{\mathrm{DI}} / \mathrm{JABS}$, or the photochemical reflectance index (PRI). The potential effect of WD on leaf absorbance $(\theta)$ and therefore $J^{A B S}$ was represented as well as the effect of WD on the maximum rate of photosynthetic electron transport ( $\mathrm{J}$ max). The effects of sucrose synthesis and phloem loading are not represented. Weak or controversial effects are represented by broken lines. Red characters and lines correspond to electron fluxes. Violet characters correspond to parameters that can be measured or calculated.

nitrate reduction at PS I could also play an important role as an alternative electron sink (Bota et al., 2004). Chlororespiration is thought to participate in the regulation of CET activity by reducing plastoquinones (Rumeau et al., 2007). Shikanai and Yamamoto (2017) also formulated the hypothesis that CET activity could be influenced by electron transfer to the NADH dehydrogenase-like (NDH) complex by chlororespiration. The NDH complex was found to represent another pathway of PSI cyclic electron transfer in angiosperms.

It is possible to assess CET activity by measuring both $\Phi_{\text {PSII }}$ and $\mathrm{P} 700$ - dependent absorption changes at $820 \mathrm{~nm}$ relative to $870 \mathrm{~nm}$ (Harbinson and Foyer, 1991; Klughammer and Schreiber, 1994; Kotakis et al., 2006; Huang et al., 2010), which is made possible by devices like the Dual-PAM of Walz. Alternatively, the electron transport fluxes from $\mathrm{Q}_{\mathrm{B}}$ to PSI acceptors, $\mathrm{J}_{0}^{\mathrm{RE}}$, expressed either as quantum yields $\left(/ \mathrm{J}_{\mathrm{ABS}}\right)$ or per reactive centers (/RC) has been suggested as an indicator of CET activity (Ripoll et al., 2016b). $\mathrm{J}_{0}^{\mathrm{RE} 1} / \mathrm{J}_{\mathrm{ABS}}$ and $\mathrm{J}_{0}^{\mathrm{RE} 1} / \mathrm{RC}$ can be derived from analysis of OJIP transients.

\section{DISSIPATION OF EXCESS ENERGY}

Leaves of water-stressed plants are commonly facing conditions characterized by an imbalance between the quantity of light energy absorbed relative to their capacity to deal with it through photosynthesis, photorespiration, or even alternative electron routes. The primary mechanism by which they transfer the absorbed light energy in excess away from photosynthetic electron transport toward heat production is energy-dependent quenching, which depends in part on the xanthophyll cycle (Horton and Ruban, 2005; Baker, 2008; Mozzo et al., 2008; García-Plazaola et al., 2012). So called non-photochemical quenching (attenuation) of ChlF, NPQ, increases as a consequence of $\mathrm{WD}$, whereas photochemical 
quenching decreases (Tezara et al., 1999). There are two possible ways to evaluate dissipation of excess energy, either by using a traditional modulated fluorimeter, or by using a high time resolution fluorimeter. The first one provides crucial information about the importance of heat dissipation relative to photochemistry for given light conditions; the second provides information that rather has to be put into perspective with other parameters to assess the global strategy of the plant under investigation (Ripoll et al., 2016b).

NPQ can be calculated as $\left(\mathrm{F}_{\mathrm{m}}-\mathrm{F}_{\mathrm{m}}^{\prime}\right) / \mathrm{F}_{\mathrm{m}}^{\prime}$ from measurements of maximal fluorescence performed on dark- $\left(\mathrm{F}_{\mathrm{m}}\right)$ and then light-adapted $\left(\mathrm{F}_{\mathrm{m}}^{\prime}\right)$ leaves (Schreiber et al., 1986; Bilger and Björkman, 1990; Bilger et al., 1995; Maxwell and Johnson, 2000; Müller et al., 2001; Kramer et al., 2004), using a standard modulated fluorimeter. Alternatively, $\mathrm{q}_{\mathrm{N}}$ can be calculated as $\left(\mathrm{F}_{\mathrm{m}}-\mathrm{F}_{\mathrm{m}}^{\prime}\right) /\left(\mathrm{F}_{\mathrm{m}}-\mathrm{F}_{0}^{\prime}\right)$ (Schreiber et al., 1986; Kooten and Snel, 1990). Note that $F_{0}^{\prime}$ may be calculated instead of measured on light-adapted leaves, according to Oxborough and Baker (1997). There are however discrepancies. Recently, Ruban (2016) proposed a novel approach for analyzing light tolerance in plants, exploiting the discrepancy between calculated and measured $\mathrm{F}_{0}^{\prime}$. It would certainly be of interest to test this approach for drought conditions.

$\mathrm{Y}_{\mathrm{NPQ}}$ and $\mathrm{Y}_{\mathrm{NO}}$, the quantum yield of light-induced nonphotochemical quenching of fluorescence (associated to $\Delta \mathrm{pH}$ and the xanthophyll cycle), and the yield of non-light induced non-photochemical quenching of fluorescence, respectively, are also useful parameters than can be easily calculated (Kramer et al., 2004). $\mathrm{Y}_{\text {NO }}$ corresponds to non-regulated dissipation of excess energy and may be used as an indicator of the stress-associated risk of photo-damage.

The new generation of portable fluorimeters, which provide the high time resolution required for performing measurements of fast ChlF induction kinetics, can be considered to facilitate analysis of heat dissipation even more easily than modulated fluorimeters since no light adaptation is required any more. But then leaves must be dark-adapted. The dissipated energy flux expressed on a PSII reaction center basis, $J^{\mathrm{DI}} / \mathrm{RC}$, can be calculated as $\mathrm{J}^{\mathrm{DI}} / \mathrm{RC}=\mathrm{J}^{\mathrm{ABS}} / \mathrm{RC}-\mathrm{J}_{0}^{\mathrm{TR}} / \mathrm{RC}$, where $\mathrm{J}^{\mathrm{ABS}} / \mathrm{RC}$ represents the average absorbed photon flux per PSII reaction center (or, alternatively, the apparent antenna size of an active PSII), and $\mathrm{J}_{0}^{\mathrm{TR}} / \mathrm{RC}$ the maximum trapped exciton flux per PSII. J ${ }^{A B S} / R C$ is calculated as $\left(M_{0} / \mathrm{V}_{\mathrm{J}}\right) /\left(\mathrm{F}_{\mathrm{v}} / \mathrm{F}_{\mathrm{m}}\right)$ with $\mathrm{M}_{0}$ the initial slope of the relative variable $\mathrm{ChlF}$ curve, and $\mathrm{V}_{\mathrm{J}}$ the value of relative variable $\mathrm{ChlF}$ at $2 \mathrm{~ms}$. $\mathrm{J}_{0}^{\mathrm{TR}} / \mathrm{RC}$ is calculated as $\mathrm{M}_{0} / \mathrm{V}_{\mathrm{J}}$ (Stirbet, 2011). J ${ }^{\mathrm{DI}}$ can also be expressed per excited cross section: $\mathrm{J}_{0}^{\mathrm{TR}} / \mathrm{CS}$. $1 /\left(\mathrm{J}^{\mathrm{ABS}} / \mathrm{RC}\right)$, often noted as RC/ABS, is the first of the three ingredients of the popular, composite Performance Index on an absorption basis $\left(\mathrm{PI}_{\mathrm{ABS}}\right.$ ) of Strasser (Strasser and Srivastava, 1995; Srivastava and Strasser, 1999; Strasser et al., 2004; Stirbet, 2011). In addition to $\mathrm{RC} / \mathrm{J}^{\mathrm{ABS}}$, $\mathrm{PI}_{\mathrm{ABS}}$ encompasses $\mathrm{F}_{\mathrm{V}} / \mathrm{F}_{0}=\left(\mathrm{F}_{\mathrm{v}} / \mathrm{F}_{\mathrm{m}}\right) /\left(1-\left(\mathrm{F}_{\mathrm{v}} / \mathrm{F}_{\mathrm{m}}\right)\right)$, an indicator of trapping probability, and $\left(1-\mathrm{V}_{\mathrm{J}}\right) / \mathrm{V}_{\mathrm{J}}$, an indicator of the performance of conversion of excitation energy to photosynthetic electron transport. $\mathrm{PI}_{\mathrm{ABS}}$ is considered as a much more sensitive and discriminating stress indicator than $\mathrm{F}_{\mathrm{v}} / \mathrm{F}_{\mathrm{m}}$ (see for instance Le, 2007), even though contradictory observations in response to WD have been reported (Ripoll et al., 2016b). Differences in $\mathrm{J}^{\mathrm{DI}} / \mathrm{RC}$ are generally discussed along with other variations in energy and electron fluxes, namely variations in the electron transport fluxes from $\mathrm{Q}_{\mathrm{A}}$ to $\mathrm{Q}_{\mathrm{B}}, \mathrm{J}_{0}^{\mathrm{ET} 2}$, and in $\mathrm{J}_{0}^{\mathrm{RE} 1}$. When compared to $\mathrm{PI}_{\mathrm{ABS}}, \mathrm{PI}_{\mathrm{ABS}}^{\mathrm{TOT}}$ actually includes an additional parameter related to electron transport flux to PSI acceptors.

Alongside parameters derived from chlorophyll $a$ fluorescence, the Photochemical Reflectance Index (PRI) of Gamon et al. (1992) may be used to evaluate the epoxidation rate of xanthophylls, which was observed to result in a major shift in reflectance at $531 \mathrm{~nm}$ compared to stable reflectance at either 515,550 , or $570 \mathrm{~nm}$. Because xanthophyll cycle pigments adjust the energy distribution at the photosynthetic reaction center, the PRI can be considered as an indicator of photosynthetic light use efficiency (LUE) and of stress (Gamon et al., 1992). Even though the PRI is highly sensitive to light conditions, it has been found to be particularly useful for measuring vegetation health status at the canopy and field scale, prior to senescence. A normalized version of the PRI has been proposed by Zarco-Tejada et al. (2013) which allows for corrections for both canopy density and chlorophyll content variations. The PRI has already been used successfully as an indirect water stress indicator (Thenot et al., 2002; Peguero-Pina et al., 2008; Suárez et al., 2008, 2009, 2010). As portable commercial sensors measuring PRI and NDVI are now available, PRI time series becomes easy to acquire. At the short-term scale, PRI is a promising physiological indicator of stresses. However, PRI value is affected by tissue structural changes, chlorophyll content level and carotenoid/chlorophyll content ratios (Sims and Gamon, 2002; Wong and Gamon, 2015). Consequently, the relationships between light use efficiency (LUE) and PRI, between $\mathrm{F}_{\mathrm{v}} / \mathrm{F}_{\mathrm{m}}$ and PRI (Stylinski et al., 2002), and between $\Delta \mathrm{F} / \mathrm{Fm}^{\prime}$ and PRI (Gamon et al., 1997), are specific of plant species and of growing condition. By using PRI values of dark-adapted leaves $\left(\mathrm{PRI}_{0}\right)$, which are highly correlated to chlorophyll content, saturating Q and soil moisture, it is possible to define PRI seasonal variations, and then to analyze short-term variations which are correlated to light interception and LUE (Hmimina et al., 2014, 2015). The occurrence of clouds affects directly and negatively PRI (Merlier et al., 2015). PRI variations are greater in sunlit upper leaves than in the shaded leaves found inside the canopy, reflecting a higher investment of the photoprotective xanthophyll cycle pigments (Gamon and Berry, 2012). Some caution should be observed when comparing PRI values among younger and mature leaves at a given time period, and when comparing PRI values at different seasons. Pigment content analysis in contrasted conditions is recommended for relevant interpretation of PRI variations. The correlation between PRI and $\mathrm{F}_{\mathrm{v}} / \mathrm{F}_{\mathrm{m}}$ is no longer verified when senescence starts. During extreme drought, PRI can become decoupled from LUE, leading to overestimates of LUE (Gamon et al., 2001; Filella et al., 2004; Nakaji et al., 2006; Rahimzadeh-Bajgiran et al., 2012).

\section{ANTIOXIDANT METABOLISM}

The antioxidant metabolism in plants encompasses enzymatic and non-enzymatic processes. It is known since long that 
there are both strongly influenced by WD (Reddy et al., 2004; Nakabayashi et al., 2014). To evaluate enzymatic processes, it is needed to measure the activities of antioxidant enzymes like superoxide dismutase and of enzymes of the antioxidant systems (Poiroux-Gonord et al., 2013). There are no non-destructive methods so far that can be used in the field to evaluate enzymatic activities. By contrast, there are field techniques for evaluating the content in non-enzymatic antioxidant molecules. [anthocyanins] and [flavonols] can be measured at least using in vivo, nondestructive measurements of ChlF based on the fluorescence excitation ratio method (Bilger et al., 1997; Agati et al., 2011). The method was developed for canopies (Ounis et al., 2001) and tested also on fruits (see for instance Betemps et al., 2012). The Dualex ${ }^{\circledR}$ and the Multiplex ${ }^{\circledR}$ systems that are used on leaves make use of a reference beam of red light (not absorbed by flavonols and anthocyanins) and one or more additional beams providing different excitation wavelengths. UV-A is strongly absorbed by flavonols whereas green light is strongly absorbed by anthocyanins (Cerovic et al., 2002, 2012; Goulas et al., 2004; Cartelat et al., 2005; Bürling et al., 2013). Diodes for detecting fluorescence emission at 590,685, and $735 \mathrm{~nm}$ allow corrections for differences in chlorophyll content in leaves since the red/far red fluorescence ratio is related to chlorophyll concentration (Hák et al., 1990; Lichtenthaler et al., 1990; Buschmann et al., 2001; Buschmann, 2007; Gameiro et al., 2016). Apparently, using either a blue or a red reference light beam to make measurements on green leaves was not found to influence results (Cerovic et al., 2002, 2012; Goulas et al., 2004; Cartelat et al., 2005; Pfündel et al., 2007; Bürling et al., 2013). It must be noted that the specific modulated fluorimeters that are used to measure [anthocyanins] and [flavonols] in leaves can be easily operated in the field with the added bonus of little influence of current climatic parameters. It must however be kept in mind that the no units data provided must be corrected to be expressed on dry matter basis.

\section{DAMAGE INDICATORS}

At some point, stress may not simply trigger acclimation mechanisms but also result in various damages (Figure 1). Most damage-related parameters that can be measured in the field derive from ChlF measurements or are indicators of leaf chlorophyll content. We propose to consider here five ChlF parameters: $F_{o}$, the relative variable $\mathrm{ChlF}$ at $300 \mu \mathrm{s}, \mathrm{NPQ}$, the normalized area of the fluorescence induction curve, and, tentatively, the probability of connectivity.

An increase in $F_{0}$ may be caused by the release of free chlorophyll from protein-pigment complexes, which results in blocked energy transfer to the PSII traps (Armond et al., 1978, 1980; Sundby et al., 1986). An increase in $\mathrm{F}_{0}$ may not be reflected in a decrease in $\mathrm{F}_{\mathrm{v}} / \mathrm{F}_{\mathrm{m}}$ when there is a concomitant decrease in $\mathrm{F}_{\mathrm{m}}$. A decrease in $\mathrm{F}_{\mathrm{m}}$ is a common occurrence in conditions of stress, since a decrease in $F_{m}$ reflects sustained engagement of zeaxanthin in a state primed for energy dissipation, i.e., the stimulation of the photoprotective mechanism known as the xanthophyll cycle (Wingler et al., 2004).

Drought may cause damage to the oxygen-evolving center (OEC) coupled with PSII (Kawakami et al., 2009), besides of degradation of D1 protein (He et al., 1995; Giardi et al., 1996), leading to inactivation of the PSII reaction centers (RC) (Liu et al., 2006; Zlatev, 2009), which may eventually lead to ROS generation as well as photoinhibition and oxidative damage (Ashraf, 2009; Gill and Tuteja, 2010). Limitation/inactivation, possibly damage of the OEC may be observed and assessed through the increase in relative variable fluorescence at $300 \mu$ s (K-step), $V_{K}$ (Srivastava et al., 1997), although such an increase may also be interpreted as a different functional antenna size (Yusuf et al., 2010). The $\mathrm{V}_{\mathrm{K}} / \mathrm{V}_{\mathrm{J}}$ ratio can also be used as a relative measurement of the functional antenna size (Yusuf et al., 2010) or of OEC inactivation/damage (Kalachanis and Manetas, 2010; see also Kotakis et al., 2014). $\mathrm{V}_{\mathrm{J}}$ stand for relative variable fluorescence at $2 \mathrm{~ms}$. A K-step occurs whenever the electron flow to the acceptor side exceeds the electron flow from the donor side. This leads to RC oxidation with a photosystem shift toward the $\mathrm{P}_{680}^{+}$form which is known to have a low fluorescence yield (Srivastava et al., 1997). Thus, OEC dissociation triggers the K-step, by inhibiting efficient electron donation to the RC (Strasser, 1997; De Ronde et al., 2004). The appearance of the K-band is associated with heat and drought stress. Christen et al. (2007) observed indeed an increase in $\mathrm{F}_{\mathrm{K}}$ as a consequence of drought. Similarly, Oukarroum et al. (2007) observed that the K-band can be exploited to analyse responses to drought stress in barley cultivars.

It was hypothesized that the repair cycle for ATP synthase components is not as active as for D1 protein (Nishiyama et al., 2001). Mahler et al. (2007) observed that ${ }^{1} \mathrm{O}_{2}$ damages result in a decrease in ATP hydrolysis and increased NPQ. Considering that ATP hydrolysis strongly correlates with ATP synthase activity, substantially increased NPQ may be an indicator of damage to ATP synthase.

$\mathrm{S}_{\mathrm{m}}$ is the normalized area of the fluorescence induction curve. $\mathrm{S}_{\mathrm{m}}$ is assumed to be proportional to the pool size of electron carriers (Yordanov et al., 2008). The plastoquinone pool may indeed decrease as a consequence of stress (Bishop, 1961; Shavit and Avron, 1963) but then probably only in case of severe stress. For example, Christen et al. (2007) observed that moderate drought did not affect $S_{\mathrm{m}}$ in grapevine.

The shape of the induction curve between 50 and $300 \mu \mathrm{s}$ (so-called L-band) is influenced by the excitation energy transfer between PSII units, commonly denoted as connectivity (Strasser and Stirbet, 1998). A more hyperbolic transient is a reflection of an increase in the energetic connectivity and a decrease can be observed as a consequence of drought (Oukarroum et al., 2007). Therefore, p, the probability of connectivity, which can be derived according to the method described by Stirbet (2011), could be an indicator of damage.

As stress intensifies, chloroplasts will ultimately break down. A large proportion of nitrogen resources are tied up in leaves, mostly in chloroplasts, and these resources can be redistributed elsewhere (Lawlor, 1993). Decreases in leaf nitrogen or chlorophyll content are therefore ultimate indicators of severe stress. There is some evidence that WD may accelerate loss of leaf nitrogen and chlorophyll, and enhance senescence as it was observed in wheat (Yang et al., 2001). Recently, Okami et al. (2016) observed that the optimal vertical distribution of leaf nitrogen content expressed on leaf mass basis, $\mathrm{N}_{\mathrm{m}}$, 
may be affected by drought in an indica cultivar of rice. But generally it takes severe stress before the structure, not purely the functioning, of the photosynthetic machinery is affected. Weak or very progressive long-term drought seems to impact only weakly, if at all, leaf nitrogen content (Sinclair et al., 2000; Damour et al., 2008).

Nitrogen content determination is time consuming but there are also indirect, fast and non-destructive methods derived from estimates of chlorophyll content (see above). It is however important to remember that the chlorophyll-nitrogen relationship depends on the growing season and on nitrogen content range (Evans, 1983). Also the influence of light intensity when using a chlorophyll meter must be taken into account since chloroplasts are known to rearrange themselves inside the cell in response to blue light intensity (Sakai et al., 2001; Kasahara et al., 2002). Parameters used in remote sensing, such as the ratio between ChlF at 735 and $700 \mathrm{~nm}$, which is linearly proportional to chlorophyll content (Gitelson et al., 1999), can be used to evaluate leaf nitrogen at leaf or plant scale. Alternatively, leaf nitrogen content per unit leaf area, $\mathrm{N}_{\mathrm{a}}$, can be estimated for instance from $\mathrm{R}_{1075} / \mathrm{R}_{735}$ reflectance ratios or, better still, from the ratio $d R / d \lambda$ at $740 \mathrm{~nm}$ (Zhao et al., 2005). More recently, Vigneau et al. (2011) proposed to use hyperspectral imaging to assess $\mathrm{N}_{\mathrm{m}}$ in wheat.

\section{CONCLUSION}

Assessing water status and the physiological responses triggered by WD has been a major challenge in plant science for decades. This challenge has become even more important in the context of global change. Nothing less than our capacity to manage dwindling water resources and to ensure food security for the world population is at stakes here. Not surprisingly,

\section{REFERENCES}

Adams, III, W. W., Zarter, C. R., Mueh, K. E., Amiard, V., and DemmigAdams, B. (2006). "Energy dissipation and photoinhibition: a continuum of photoprotection," in Photoprotection, Photoinhibition, Gene Regulation, and Environment, eds B. Demmig-Adams, W. W. Adams III, and A. K. Mattoo (Dordrecht: Springer), 49-64. doi: 10.1007/1-4020-3579-9_5

Agati, G., Cerovic, Z. G., Pinelli, P., and Tattini, M. (2011). Light-induced accumulation of ortho-dihydroxylated flavonoids as non-destructively monitored by chlorophyll fluorescence excitation techniques. Environ. Exp. Bot. 73, 3-9. doi: 10.1016/j.envexpbot.2010.10.002

Allen, J. F. (2002). Photosynthesis of ATP, electrons, proton pumps, rotors, and poise. Cell 110, 273-276. doi: 10.1016/S0092-8674(02)00870-X

Armond, P. A., Björkman, O., and Staehelin, L. A. (1980). Dissociation of supramolecular complexes in chloroplast membranes A manifestation of heat damage to the photosynthetic apparatus. Biochim. Biophys. Acta 601, 433-442. doi: 10.1016/0005-2736(80) 90547-7

Armond, P. A., Schreiber, U., and Björkman, O. (1978). Photosynthetic acclimation to temperature in the desert shrub, Larrea divaricata II. Lightharvesting efficiency and electron transport. Plant Physiol. 61, 411-415. doi: 10.1104/pp.61.3.411

Ashraf, M. (2009). Biotechnological approach of improving plant salt tolerance using antioxidants as markers. Biotechnol. Adv. 27, 84-93. doi: 10.1016/j.biotechadv.2008.09.003 we have been observing for several years an outburst of new concepts, innovative techniques and novel parameters. Obviously, parameters derived from ChlF measurements, either alone or combined with parameters derived from gas exchange techniques, will play an increasingly important role in analyzing the impact of WD on photosynthesis. Most of these parameters being easy to obtain in the field, it is our belief that they will be increasingly exploited to explore dimensions of the complexity of plants' responses to WD that have been neglected so far in agronomic studies notably. We may have a relatively precise vision of the short-term molecular response of a potted Arabidopsis plant, grown in the stable environment of a phytotron, when subjected to a brutal interruption of water supply; however we are far from being able to predict what happens in the field to plants of variable genetic background and developmental stages, submitted to periods of more or less severe drought, possibly interrupted by periods of recovery, while other environmental factors, including pests and pathogens, fluctuate and interact with them (Ripoll et al., 2016a).

\section{AUTHOR CONTRIBUTIONS}

LB contributed specifically to the stomatal conductance and mesophyll conductance sections. He is also the author of all the parts of the text dealing with remote sensing techniques. JA contributed namely to the section about damage indicators. $\mathrm{LU}$ is the major contributor to all other sections.

\section{FUNDING}

Patrice This, director the AGAP team will pay the bill by credit card.

Atkin, O. K., and Macherel, D. (2009). The crucial role of plant mitochondria in orchestrating drought tolerance. Ann. Bot. 103, 581-597. doi: $10.1093 / \mathrm{aob} / \mathrm{mcn} 094$

Baker, N. R. (2008). Chlorophyll fluorescence: a probe of photosynthesis in vivo. Annu. Rev. Plant Biol. 59, 89-113. doi: 10.1146/annurev.arplant.59.032607.092759

Bauerle, W. L., Weston, D. J., Bowden, J. D., Dudley, J. B., and Toler, J. E. (2004). Leaf absorptance of photosynthetically active radiation in relation to chlorophyll meter estimates among woody plant species. Sci. Hortic. 101, 169-178. doi: 10.1016/j.scienta.2003.09.010

Bellasio, C., Beerling, D. J., and Griffiths, H. (2016). An Excel tool for deriving key photosynthetic parameters from combined gas exchange and chlorophyll fluorescence: theory and practice. Plant Cell Environ. 39, 1180-1197. doi: 10.1111 pce. 12560

Berera, R., van Grondelle, R., and Kennis, J. T. (2009). Ultrafast transient absorption spectroscopy: principles and application to photosynthetic systems. Photosyn. Res. 101, 105-118. doi: 10.1007/s11120-0099454-y

Betemps, D. L., Fachinello, J. C., Galarça, S. P., Portela, N. M., Remorini, D., Massai, R., et al. (2012). Non-destructive evaluation of ripening and quality traits in apples using a multiparametric fluorescence sensor. J. Sci. Food Agric. 92, 1855-1864. doi: 10.1002/jsfa.5552

Bilger, W., and Björkman, O. (1990). Role of the xanthophyll cycle in photoprotection elucidated by measurements of light-induced absorbance changes, fluorescence and photosynthesis in leaves of Hedera canariensis. Photosyn. Res. 25, 173-185. doi: 10.1007/BF00033159 
Bilger, W., Schreiber, U., and Bock, M. (1995). Determination of the quantum efficiency of photosystem II and of non-photochemical quenching of chlorophyll fluorescence in the field. Oecologia 102, 425-432. doi: 10.1007/BF00341354

Bilger, W., Veit, M., Schreiber, L., and Schreiber, U. (1997). Measurement of leaf epidermal transmittance of UV radiation by chlorophyll fluorescence. Physiol. Plant. 101, 754-763. doi: 10.1111/j.1399-3054.1997.tb01060.x

Bishop, N. (1961). "The Possible Role of Plastoquinone (QA-) in the Electron Transport System of Photosynthesis," in Ciba Foundation Symposium-Quinones in Electron Transport (Chichester, UK: Wiley Online Library), 385-424.

Björkman, O., and Demmig, B. (1987). Photon yield of $\mathrm{O}_{2}$ evolution and chlorophyll fluorescence characteristics at $77 \mathrm{~K}$ among vascular plants of diverse origins. Planta 170, 489-504. doi: 10.1007/BF00402983

Blum, A. (2017) Osmotic adjustment is a prime drought stress adaptive engine in support of plant production. Plant Cell Environ. 40, 4-10. doi: $10.1111 /$ pce. 12800

Bongi, G., and Loreto, F. (1989). Gas-exchange properties of saltstressed olive (Olea europea L.) leaves. Plant Physiol. 90, 1408-1416. doi: 10.1104/pp.90.4.1408

Bota, J., Medrano, H., and Flexas, J. (2004). Is photosynthesis limited by decreased Rubisco activity and RuBP content under progressive water stress? New Phytol. 162, 671-681. doi: 10.1111/j.1469-8137.2004.01056.x

Boyer, J. S. (1982). Plant productivity and environment. Science 218, 443-448. doi: $10.1126 /$ science.218.4571.443

Brooks, A., and Farquhar, G. (1985). Effect of temperature on the $\mathrm{CO}_{2} / \mathrm{O}_{2}$ specificity of ribulose-1, 5-bisphosphate carboxylase/oxygenase and the rate of respiration in the light. Planta 165, 397-406. doi: 10.1007/BF00392238

Buckley, T. N., and Diaz-Espejo, A. (2015). Reporting estimates of maximum potential electron transport rate. New Phytol. 205, 14-17. doi: $10.1111 / \mathrm{nph} .13018$

Buckley, T. N., and Warren, C. R. (2014). The role of mesophyll conductance in the economics of nitrogen and water use in photosynthesis. Photosyn. Res. 119, 77-88. doi: 10.1007/s11120-013-9825-2

Bürling, K., Cerovic, Z. G., Cornic, G., Ducruet, J.-M., Noga, G., and Hunsche, M. (2013). Fluorescence-based sensing of drought-induced stress in the vegetative phase of four contrasting wheat genotypes. Environ. Exp. Bot. 89, 51-59. doi: 10.1016/j.envexpbot.2013.01.003

Busch, F. (2013). Current methods for estimating the rate of photorespiration in leaves. Plant Biol. 15, 648-655. doi: 10.1111/j.1438-8677.2012.00694.x

Buschmann, C. (2007). Variability and application of the chlorophyll fluorescence emission ratio red/far-red of leaves. Photosyn. Res. 92, 261-271. doi: 10.1007/s11120-007-9187-8

Buschmann, C., Langsdorf, G., and Lichtenthaler, H. (2001). Imaging of the blue, green, and red fluorescence emission of plants: an overview. Photosynthetica 38, 483-491. doi: 10.1023/A:1012440903014

Cartelat, A., Cerovic, Z., Goulas, Y., Meyer, S., Lelarge, C., Prioul, J.-L., et al. (2005). Optically assessed contents of leaf polyphenolics and chlorophyll as indicators of nitrogen deficiency in wheat (Triticum aestivum L.). Field Crops Res. 91, 35-49. doi: 10.1016/j.fcr.2004.05.002

Cerovic, Z. C., Masdoumier, G., Ben Ghozlen, N., and Latouche, G. (2012). A new optical leaf-clip meter for simultaneous non-destructive assessment of leaf chlorophyll and epidermal flavonoids. Physiol. Plant. 146, 251-260. doi: 10.1111/j.1399-3054.2012.01639.x

Cerovic, Z., Ounis, A., Cartelat, A., Latouche, G., Goulas, Y., Meyer, S., et al. (2002). The use of chlorophyll fluorescence excitation spectra for the non-destructive in situ assessment of UV-absorbing compounds in leaves. Plant Cell Environ. 25, 1663-1676. doi: 10.1046/j.1365-3040.2002.00942.x

Chastain, D. R., Snider, J. L., Collins, G. D., Perry, C. D., Whitaker, J., and Byrd, S. A. (2014). Water deficit in field-grown Gossypium hirsutum primarily limits net photosynthesis by decreasing stomatal conductance, increasing photorespiration, and increasing the ratio of dark respiration to gross photosynthesis. J. Plant Physiol. 171, 1576-1585. doi: 10.1016/j.jplph.2014.07.014

Chaves, M., Flexas, J., and Pinheiro, C. (2009). Photosynthesis under drought and salt stress: regulation mechanisms from whole plant to cell. Ann. Bot. 103, 551-560. doi: $10.1093 / \mathrm{aob} / \mathrm{mcn} 125$

Christen, D., Schönmann, S., Jermini, M., Strasser, R. J., and Défago, G. (2007). Characterization and early detection of grapevine (Vitis vinifera) stress responses to esca disease by in situ chlorophyll fluorescence and comparison with drought stress. Environ. Exp. Bot. 60, 504-514. doi: 10.1016/j.envexpbot.2007.02.003

Cornic, G., and Fresneau, C. (2002). Photosynthetic carbon reduction and carbon oxidation cycles are the main electron sinks for photosystem II activity during a mild drought. Ann. Bot. 89, 887-894. doi: 10.1093/aob/mcf064

Damour, G., Simonneau, T., Cochard, H., and Urban, L. (2010). An overview of models of stomatal conductance at the leaf level. Plant Cell Environ. 33, 1419-1438. doi: 10.1111/j.1365-3040.2010.02181.x

Damour, G., Vandame, M., and Urban, L. (2008). Long-term drought modifies the fundamental relationships between light exposure, leaf nitrogen content and photosynthetic capacity in leaves of the lychee tree (Litchi chinensis). J. Plant Physiol. 165, 1370-1378. doi: 10.1016/j.jplph.2007.10.014

Davis, J., Arkebauer, T., Norman, J., and Brandle, J. (1987). Rapid field measurement of the assimilation rate versus internal $\mathrm{CO}_{2}$ concentration relationship in green ash (Fraxinus pennsylvanica Marsh.): the influence of light intensity. Tree Physiol. 3, 387-392. doi: 10.1093/treephys/3.4.387

De Ronde, J., Cress, W., Krüger, G., Strasser, R., and Van Staden, J. (2004). Photosynthetic response of transgenic soybean plants, containing an Arabidopsis P5CR gene, during heat and drought stress. J. Plant Physiol. 161, 1211-1224. doi: 10.1016/j.jplph.2004.01.014

Di Marco, G., Manes, F., Tricoli, D., and Vitale, E. (1990). Fluorescence parameters measured concurrently with net photosynthesis to investigate chloroplastic $\mathrm{CO}_{2}$ concentration in leaves of Quercus ilex L. J. Plant Physiol. 136, 538-543. doi: 10.1016/S0176-1617(11)80210-5

Dubois, J. J. B., Fiscus, E. L., Booker, F. L., Flowers, M. D., and Reid, C. D. (2007). Optimizing the statistical estimation of the parameters of the Farquharvon Caemmerer-Berry model of photosynthesis. New Phytol. 176, 402-414. doi: 10.1111/j.1469-8137.2007.02182.x

Ducruet, J.-M., and Vass, I. (2009). Thermoluminescence: experimental. Photosyn. Res. 101, 195-204. doi: 10.1007/s11120-009-9436-0

Duursma, R. A. (2015). Plantecophys-an R package for analysing and modelling leaf gas exchange data. PLoS ONE 10:e0143346. doi: 10.1371 /journal.pone. 0143346

Duysens, L., and Sweers, H. (1963). "Mechanism of two photochemical reactions in algae as studied by means of fluorescence," in Studies on Microalgae and Photosynthetic Bacteria (Tokyo: University Tokyo Press), 353-372.

Ennahli, S., and Earl, H. J. (2005). Physiological limitations to photosynthetic carbon assimilation in cotton under water stress. Crop Sci. 45, 2374-2382. doi: $10.2135 /$ cropsci2005.0147

Ethier, G., and Livingston, N. (2004). On the need to incorporate sensitivity to $\mathrm{CO}_{2}$ transfer conductance into the Farquhar-von CaemmererBerry leaf photosynthesis model. Plant Cell Environ. 27, 137-153. doi: 10.1111/j.1365-3040.2004.01140.x

Evans, J. R. (1983). Nitrogen and photosynthesis in the flag leaf of wheat (Triticum aestivum L.). Plant Physiol. 72, 297-302. doi: 10.1104/pp.72.2.297

Evans, J. R. (1989). Photosynthesis and nitrogen relationships in leaves of C3 plants. Oecologia 78, 9-19. doi: 10.1007/BF00377192

Evans, J., Sharkey, T., Berry, J., and Farquhar, G. (1986). Carbon isotope discrimination measured concurrently with gas exchange to investigate $\mathrm{CO}_{2}$ diffusion in leaves of higher plants. Funct. Plant Biol. 13, 281-292.

Farooq, M., Wahid, A., Kobayashi, N., Fujita, D., and Basra, S. (2009). Plant drought stress: effects, mechanisms and management. Agron. Sust. Develop. 29, 185-212. doi: 10.1051/agro:2008021

Farquhar, G. D., von Caemmerer, S., and Berry, J. A. (2001). Models of photosynthesis. Plant Physiol. 125, 42-45. doi: 10.1104/pp.125.1.42

Farquhar, G., von Caemmerer, S. Y., and Berry, J. (1980). A biochemical model of photosynthetic $\mathrm{CO}_{2}$ assimilation in leaves of C3 species. Planta 149, 78-90. doi: $10.1007 / \mathrm{BF} 00386231$

Field, C., and Mooney, H. (1983). Leaf age and seasonal effects on light, water, and nitrogen use efficiency in a California shrub. Oecologia 56, 348-355. doi: 10.1007/BF00379711

Filella, I., Peñuelas, J., Llorens, L., and Estiarte, M. (2004). Reflectance assessment of seasonal and annual changes in biomass and $\mathrm{CO}_{2}$ uptake of a Mediterranean shrubland submitted to experimental warming and drought. Remote Sens. Environ. 90, 308-318. doi: 10.1016/j.rse.2004.01.010

Flexas, J., Barbour, M. M., Brendel, O., Cabrera, H. M., Carriqui, M., DiazEspejo, A., et al. (2012). Mesophyll diffusion conductance to $\mathrm{CO}_{2}$ : an 
unappreciated central player in photosynthesis. Plant Sci. 193, 70-84. doi: 10.1016/j.plantsci.2012.05.009

Flexas, J., Bota, J., Loreto, F., Cornic, G., and Sharkey, T. (2004). Diffusive and metabolic limitations to photosynthesis under drought and salinity in C3 plants. Plant Biol. 6, 269-279. doi: 10.1055/s-2004-820867

Flexas, J., Ortuno, M., Ribas-Carbo, M., Diaz-Espejo, A., Florez-Sarasa, I., and Medrano, H. (2007). Mesophyll conductance to $\mathrm{CO}_{2}$ in Arabidopsis thaliana. New Phytol. 175, 501-511. doi: 10.1111/j.1469-8137.2007.02111.x

Galmès, J., Abadia, A., Medrano, H., and Flexas, J. (2007). Photosynthesis and photoprotection responses to water stress in the wild-extinct plant Lysimachia minoricensis. Environ. Exp. Bot. 60, 308-317. doi: 10.1016/j.envexpbot.2006.12.016

Gameiro, C., Utkin, A., Cartaxana, P., da Silva, J. M., and Matos, A. (2016). The use of laser induced chlorophyll fluorescence (LIF) as a fast and non-destructive method to investigate water deficit in Arabidopsis. Agric. Water Manag. 164, 127-136. doi: 10.1016/j.agwat.2015.09.008

Gamon, J. A., and Berry, J. A. (2012). Facultative and constitutive pigment effects on the photochemical reflectance index (PRI) in sun and shade conifer needles. Isr. J. Plant Sci. 60, 85-95. doi: 10.1560/IJPS.60.1-2.85

Gamon, J. A., Field, C. B., Fredeen, A. L., and Thayer, S. (2001). Assessing photosynthetic downregulation in sunflower stands with an optically-based model. Photosynth. Res. 67, 113-125. doi: 10.1023/A:1010677605091

Gamon, J. A., Peñuelas, J., and Field, C. B. (1992). A narrow-waveband spectral index that tracks diurnal changes in photosynthetic efficiency. Remote Sens. Environ. 41, 35-44. doi: 10.1016/0034-4257(92)90059-S

Gamon, J. A., Serrano, L., and Surfus, J. S. (1997). The photochemical reflectance index: an optical indicator of photosynthetic radiation use efficiency across species, functional types, and nutrient levels. Oecologia 112, 492-501. doi: $10.1007 / \mathrm{s} 004420050337$

García-Plazaola, J., Esteban, R., Fernández-Marín, B., Kranner, I., and Porcar-Castell, A. (2012). Thermal energy dissipation and xanthophyll cycles beyond the Arabidopsis model. Photosyn. Res. 113, 89-103. doi: 10.1007/s11120-012-9760-7

Genty, B., Briantais, J.-M., and Baker, N. R. (1989). The relationship between the quantum yield of photosynthetic electron transport and quenching of chlorophyll fluorescence. Biochim. Biophys. Acta 990, 87-92. doi: 10.1016/S0304-4165(89)80016-9

Genty, B., Briantais, J.-M., and Da Silva, J. B. V. (1987). Effects of drought on primary photosynthetic processes of cotton leaves. Plant Physiol. 83, 360-364. doi: 10.1104/pp.83.2.360

Giardi, M., Cona, A., Geiken, B., Kuçera, T., Masojidek, J., and Mattoo, A. (1996). Long-term drought stress induces structural and functional reorganization of photosystem II. Planta 199, 118-125. doi: 10.1007/BF00196888

Gill, S. S., and Tuteja, N. (2010). Reactive oxygen species and antioxidant machinery in abiotic stress tolerance in crop plants. Plant Physiol. Biochem. 48, 909-930. doi: 10.1016/j.plaphy.2010.08.016

Gitelson, A. A., Buschmann, C., and Lichtenthaler, H. K. (1999). The chlorophyll fluorescence ratio $\mathrm{F} 735 / \mathrm{F} 700$ as an accurate measure of the chlorophyll content in plants. Remote Sens. Environ. 69, 296-302. doi: 10.1016/S0034-4257(99)00023-1

Goltsev, V., Kalaji, H., Paunov, M., Baba, W., Horaczek, T., Mojski, J., et al. (2016). Variable chlorophyll fluorescence and its use for assessing physiological condition of plant photosynthetic apparatus. Russ. J. Plant Physiol. 63, 869-893. doi: $10.1134 /$ S1021443716050058

Goltsev, V., Zaharieva, I., Chernev, P., and Strasser, R. J. (2009). Delayed fluorescence in photosynthesis. Photosyn. Res. 101, 217-232. doi: 10.1007/s11120-009-9451-1

Goulas, Y., Cerovic, Z. G., Cartelat, A., and Moya, I. (2004). Dualex: a new instrument for field measurements of epidermal ultraviolet absorbance by chlorophyll fluorescence. Appl. Opt. 43, 4488-4496. doi: 10.1364/AO.43. 004488

Gu, J., Yin, X., Stomph, T., and Struik, P. C. (2014). Can exploiting natural genetic variation in leaf photosynthesis contribute to increasing rice productivity? A simulation analysis. Plant Cell Environ. 37, 22-34. doi: 10.1111/pce.12173

Gu, J., Yin, X., Stomph, T.-J., Wang, H., and Struik, P. C. (2012). Physiological basis of genetic variation in leaf photosynthesis among rice (Oryza sativa L.) introgression lines under drought and well-watered conditions. J. Exp. Bot. 63, 5137-5153. doi: 10.1093/jxb/ers170
Hák, R., Lichtenthaler, H., and Rinderle, U. (1990). Decrease of the chlorophyll fluorescence ratio F690/F730 during greening and development of leaves. Radiat. Environ. Biophys. 29, 329-336. doi: 10.1007/BF01210413

Han, J.-M., Meng, H.-F., Wang, S.-Y., Jiang, C.-D., Liu, F., Zhang, W.-F., et al. (2016). Variability of mesophyll conductance and its relationship with water use efficiency in cotton leaves under drought pretreatment. J. Plant Physiol. 194, 61-71. doi: 10.1016/j.jplph.2016.03.014

Hanjra, M. A., and Qureshi, M. E. (2010). Global water crisis and future food security in an era of climate change. Food Policy 35, 365-377. doi: 10.1016/j.foodpol.2010.05.006

Harbinson, J., and Foyer, C. H. (1991). Relationships between the Efficiencies of Photosystems I and II and Stromal Redox State in $\mathrm{CO}_{2}$-free air evidence for cyclic electron flow in vivo. Plant Physiol. 97, 41-49. doi: 10.1104/pp.97.1.41

Harley, P. C., Loreto, F., Di Marco, G., and Sharkey, T. D. (1992). Theoretical considerations when estimating the mesophyll conductance to $\mathrm{CO}_{2}$ flux by analysis of the response of photosynthesis to $\mathrm{CO}_{2}$. Plant Physiol. 98, 1429-1436. doi: 10.1104/pp.98.4.1429

Harley, P., Thomas, R., Reynolds, J., and Strain, B. (1992). Modelling photosynthesis of cotton grown in elevated $\mathrm{CO}_{2}$. Plant Cell Environ. 15, 271-282. doi: 10.1111/j.1365-3040.1992.tb00974.x

He, J. X., Wang, J., and Liang, H. G. (1995). Effects of water stress on photochemical function and protein metabolism of photosystem II in wheat leaves. Physiol. Plant. 93, 771-777. doi: 10.1111/j.1399-3054.1995.tb05130.x

Hmimina, G., Dufrêne, E., and Soudani, K. (2014). Relationship between photochemical reflectance index and leaf ecophysiological and biochemical parameters under two different water statuses: towards a rapid and efficient correction method using real-time measurements. Plant Cell Environ. 37, 473-487. doi: 10.1111/pce.12171

Hmimina, G., Merlier, E., Dufrêne, E., and Soudani, K. (2015). Deconvolution of pigment and physiologically related photochemical reflectance index variability at the canopy scale over an entire growing season. Plant Cell Environ. 38, 1578-1590. doi: 10.1111/pce.12509

Holzwarth, A. (2008). "Ultrafast primary reactions in the photosystems of oxygenevolving organisms," in Ultrashort Laser Pulses in Biology and Medicine (Springer), 141-164.

Horton, P., and Ruban, A. (2005). Molecular design of the photosystem II light-harvesting antenna: photosynthesis and photoprotection. J. Exp. Bot. 56, 365-373. doi: 10.1093/jxb/eri023

Huang, W., Zhang, S.-B., and Cao, K.-F. (2010). Stimulation of cyclic electron flow during recovery after chilling-induced photoinhibition of PSII. Plant Cell Physiol. 51, 1922-1928. doi: 10.1093/pcp/pcq144

Idso, S., Jackson, R., Pinter, P., Reginato, R., and Hatfield, J. (1981). Normalizing the stress-degree-day parameter for environmental variability. Agric. Meteorol. 24, 45-55. doi: 10.1016/0002-1571(81)90032-7

IPCC (2014). Climate Change 2014. Synthesis report, Summary for Policy Makers. Jackson, R., Idso, S., Reginato, R., and Pinter, P. (1981). Canopy temperature as a crop water stress indicator. Water Resour. Res. 17, 1133-1138. doi: 10.1029/WR017i004p01133

Kacira, M., Ling, P., and Short, T. (2002). Establishing crop water stress index (CWSI) threshold values for early, non-contact detection of plant water stress. Trans. ASAE 45, 775-780. doi: 10.13031/2013.8844

Kalachanis, D., and Manetas, Y. (2010). Analysis of fast chlorophyll fluorescence rise (O-J-I-P) curves in green fruits indicates electron flow limitations at the donor side of PSII and the acceptor sides of both photosystems. Physiol. Plant. 139, 313-323. doi: 10.1111/j.1399-3054.2010.01362.x

Kalaji, H. M., Schansker, G., Ladle, R. J., Goltsev, V., Bosa, K., Allakhverdiev, S. I., et al. (2014). Frequently asked questions about in vivo chlorophyll fluorescence: practical issues. Photosyn. Res. 122, 121-158. doi: 10.1007/s11120-014-0024-6

Kanazawa, A., and Kramer, D. M. (2002). In vivo modulation of nonphotochemical exciton quenching (NPQ) by regulation of the chloroplast ATP synthase. Proc. Natl. Acad. Sci. U.S.A. 99, 12789-12794. doi: 10.1073/pnas.182427499

Kasahara, M., Kagawa, T., Oikawa, K., Suetsugu, N., Miyao, M., and Wada, M. (2002). Chloroplast avoidance movement reduces photodamage in plants. Nature 420, 829-832. doi: 10.1038/nature01213

Kattge, J., Knorr, W., Raddatz, T., and Wirth, C. (2009). Quantifying photosynthetic capacity and its relationship to leaf nitrogen content for global-scale terrestrial biosphere models. Glob. Chang. Biol. 15, 976-991. doi: $10.1111 /$ j.1365-2486.2008.01744.x 
Kawakami, K., Umena, Y., Kamiya, N., and Shen, J.-R. (2009). Location of chloride and its possible functions in oxygen-evolving photosystem II revealed by X-ray crystallography. Proc. Natl. Acad. Sci. U.S.A. 106, 8567-8572. doi: 10.1073/pnas.0812797106

Kellomäki, S., and Wang, K.-Y. (1997). Photosynthetic responses of Scots pine to elevated $\mathrm{CO}_{2}$ and nitrogen supply: results of a branch-in-bag experiment. Tree Physiol. 17, 231-240. doi: 10.1093/treephys/17.4.231

Klughammer, C., and Schreiber, U. (1994). An improved method, using saturating light pulses, for the determination of photosystem I quantum yield via P700+-absorbance changes at $830 \mathrm{~nm}$. Planta 192, 261-268. doi: 10.1007/BF01089043

Kok, B. (1948). A critical consideration of the quantum yield of Chlorella photosynthesis. Enzymologia 13, 1-56.

Kooten, O., and Snel, J. F. (1990). The use of chlorophyll fluorescence nomenclature in plant stress physiology. Photosyn. Res. 25, 147-150. doi: $10.1007 /$ BF00033156

Kotakis, C., Kyzeridou, A., and Manetas, Y. (2014). Photosynthetic electron flow during leaf senescence: evidence for a preferential maintenance of photosystem I activity and increased cyclic electron flow. Photosynthetica 52, 413-420. doi: 10.1007/s11099-014-0046-5

Kotakis, C., Petropoulou, Y., Stamatakis, K., Yiotis, C., and Manetas, Y. (2006). Evidence for active cyclic electron flow in twig chlorenchyma in the presence of an extremely deficient linear electron transport activity. Planta 225, 245-253. doi: 10.1007/s00425-006-0327-8

Kramer, D. M., Johnson, G., Kiirats, O., and Edwards, G. E. (2004). New fluorescence parameters for the determination of QA redox state and excitation energy fluxes. Photosyn. Res. 79, 209-218. doi: 10.1023/B:PRES.0000015391.99477.0d

Laisk, A. (1977). Kinetics of Photosynthesis and Photorespiration in C3 Plants. Moscow: Nauka.

Laisk, A., and Oja, V. (1998). Dynamics of Leaf Photosynthesis: Rapid-Response Measurements and their Interpretations. Collingwood, VIC: CSIRO Publishing.

Lawlor, D. W. (1993). Photosynthesis: Molecular, Physiological and Environmental Processes. Harlow, UK: Longman Scientific \& Technical.

Lawlor, D. W., and Tezara, W. (2009). Causes of decreased photosynthetic rate and metabolic capacity in water-deficient leaf cells: a critical evaluation of mechanisms and integration of processes. Ann. Bot. 103, 561-579. doi: $10.1093 / \mathrm{aob} / \mathrm{mcn} 244$

Lawlor, D., and Cornic, G. (2002). Photosynthetic carbon assimilation and associated metabolism in relation to water deficits in higher plants. Plant Cell Environ. 25, 275-294. doi: 10.1046/j.0016-8025.2001.00814.x

Le, B. T. (2007). Comparative Ecophysiology of Graptophyllum Species in Australia. Ph.D. Thesis of the University of Queensland, Brisbane.

Lichtenthaler, H. K., Hak, R., and Rinderle, U. (1990). The chlorophyll fluorescence ratio F690/F730 in leaves of different chlorophyll content. Photosyn. Res. 25, 295-298. doi: 10.1007/BF00033170

Liu, N.-,y., Ko, S.-S., Yeh, K.-C., and Charng, Y.-Y. (2006). Isolation and characterization of tomato Hsa32 encoding a novel heat-shock protein. Plant Sci. 170, 976-985. doi: 10.1016/j.plantsci.2006.01.008

Logan, B. A., Adams, W. W., and Demmig-Adams, B. (2007). Viewpoint: avoiding common pitfalls of chlorophyll fluorescence analysis under field conditions. Funct. Plant Biol. 34, 853-859. doi: 10.1071/FP07113

Loriaux, S., Avenson, T., Welles, J., McDermitt, D., Eckles, R., Riensche, B., et al. (2013). Closing in on maximum yield of chlorophyll fluorescence using a single multiphase flash of sub-saturating intensity. Plant Cell Environ. 36, 1755-1770. doi: $10.1111 /$ pce. 12115

Mahler, H., Wuennenberg, P., Linder, M., Przybyla, D., Zoerb, C., Landgraf, F., et al. (2007). Singlet oxygen affects the activity of the thylakoid ATP synthase and has a strong impact on its $\gamma$ subunit. Planta 225, 1073-1083. doi: 10.1007/s00425-006-0416-8

Martin, M., Casano, L. M., Zapata, J. M., Guéra, A., Del Campo, E. M., Schmitz-Linneweber, C., et al. (2004). Role of thylakoid Ndh complex and peroxidase in the protection against photo-oxidative stress: fluorescence and enzyme activities in wild-type and ndhF-deficient tobacco. Physiol. Plant. 122, 443-452. doi: 10.1111/j.1399-3054.2004. 00417.x

Martin-StPaul, N. K., Limousin, J.-M., Rodriguez-Calcerrada, J., Ruffault, J., Rambal, S., Letts, M. G., et al. (2012). Photosynthetic sensitivity to drought varies among populations of Quercus ilex along a rainfall gradient. Funct. Plant Biol. 39, 25-37. doi: 10.1071/FP11090

Massacci, A., Nabiev, S., Pietrosanti, L., Nematov, S., Chernikova, T., Thor, K., et al. (2008). Response of the photosynthetic apparatus of cotton (Gossypium hirsutum) to the onset of drought stress under field conditions studied by gas-exchange analysis and chlorophyll fluorescence imaging. Plant Physiol. Biochem. 46, 189-195. doi: 10.1016/j.plaphy.2007.10.006

Massantini, F., Masoni, A., Mariotti, M., and Volterrani, M. (1990). "Effects of increasing water stress on reflectance, absorptance and transmittance of Amaranthus leaves," in Proceedings of the First Congress of the ESA (Paris), 83-84.

Maxwell, K., and Johnson, G. N. (2000). Chlorophyll fluorescence-a practical guide. J. Exp. Bot. 51, 659-668. doi: 10.1093/jexbot/51.345.659

McDermitt, D., Norman, J., Davis, J., Ball, T., Arkebauer, T., Welles, J., et al. (1989). " $\mathrm{CO}_{2}$ response curves can be measured with a field-portable closedloop photosynthesis system," in Annales des Sciences Forestieres (Amsterdam: EDP Sciences), 416s-420s.

Merlier, E., Hmimina, G., Dufrêne, E., and Soudani, K. (2015). Explaining the variability of the photochemical reflectance index (PRI) at the canopy-scale: disentangling the effects of phenological and physiological changes. J. Photochem. Photobiol. B Biol. 151, 161-171. doi: 10.1016/j.jphotobiol.2015.08.006

Misra, A., Dilnawaz, F., Misra, M., and Biswal, A. (2001). Thermoluminescence in chloroplasts as an indicator of alterations in photosystem 2 reaction centre by biotic and abiotic stresses. Photosynthetica 39, 1-9. doi: 10.1023/A:1012480114479

Mittler, R. (2006). Abiotic stress, the field environment and stress combination. Trends Plant Sci. 11, 15-19. doi: 10.1016/j.tplants.2005.11.002

Mori, I. C., Rhee, J., Shibasaka, M., Sasano, S., Kaneko, T., Horie, T., et al. (2014). $\mathrm{CO}_{2}$ transport by PIP2 aquaporins of Barley. Plant Cell Physiol. 55, 251-257. doi: $10.1093 / \mathrm{pcp} / \mathrm{pcu} 003$

Moualeu-Ngangue, D. P., Chen, T.-W., and Stützel, H. (2017). A new method to estimate photosynthetic parameters through net assimilation rate-intercellular space $\mathrm{CO}_{2}$ concentration $\left(\mathrm{A}-\mathrm{C}_{\mathrm{i}}\right)$ curve and chlorophyll fluorescence measurements. New Phytol. 213, 1543-1554. doi: 10.1111/nph.14260

Mozzo, M., Dall'Osto, L., Hienerwadel, R., Bassi, R., and Croce, R. (2008). Photoprotection in the antenna complexes of photosystem II: role of individual xanthophylls in chlorophyll triplet quenching. J. Biol. Chem. 283, 6184-6192. doi: 10.1074/jbc.M708961200

Müller, P., Li, X.-P., and Niyogi, K. K. (2001). Non-photochemical quenching. A response to excess light energy. Plant Physiol. 125, 1558-1566. doi: $10.1104 / p p .125 .4 .1558$

Murchie, E., and Lawson, T. (2013). Chlorophyll fluorescence analysis: a guide to good practice and understanding some new applications. J. Exp. Bot. 64, 3983-3998. doi: 10.1093/jxb/ert208

Nakabayashi, R., Yonekura-Sakakibara, K., Urano, K., Suzuki, M., Yamada, Y., Nishizawa, T., et al. (2014). Enhancement of oxidative and drought tolerance in Arabidopsis by overaccumulation of antioxidant flavonoids. Plant J. 77, 367-379. doi: 10.1111/tpj.12388

Nakaji, T., Oguma, H., and Fujinuma, Y. (2006). Seasonal changes in the relationship between photochemical reflectance index and photosynthetic light use efficiency of Japanese larch needles. Int. J. Remote Sens. 27, 493-509. doi: 10.1080/01431160500329528

Nambiar, E. S., and Sands, R. (1993). Competition for water and nutrients in forests. Can. J. For. Res. 23, 1955-1968. doi: 10.1139/x93-247

Nishiyama, Y., Yamamoto, H., Allakhverdiev, S. I., Inaba, M., Yokota, A., and Murata, N. (2001). Oxidative stress inhibits the repair of photodamage to the photosynthetic machinery. EMBO J. 20, 5587-5594. doi: $10.1093 / \mathrm{emboj} / 20.20 .5587$

Niyogi, K. K. (2000). Safety valves for photosynthesis. Curr. Opin. Plant Biol. 3, 455-460. doi: 10.1016/S1369-5266(00)00113-8

Nobel, P. S. (1999). Physicochemical and Environmental Plant Physiology. Oxford, UK: Academic Press.

Nobel, P. S. (2009). Photochemistry of Photosynthesis, Physicochemical and Environmental Plant Physiology, 4th Edn. San Diego, CA: Academic Press.

Noctor, G., Veljovic-Jovanovic, S., Driscoll, S., Novitskaya, L., and Foyer, C. H. (2002). Drought and oxidative load in the leaves of C-3 plants: a predominant role for photorespiration? Ann. Bot. 89, 841-850. doi: 10.1093/aob/mcf096 
Okami, M., Kato, Y., and Yamagishi, J. (2016). Canopy architecture and leaf nitrogen distribution of rice (Oryza sativa $\mathrm{L}$.) under chronic soil water deficit. J. Agron. Crop Sci. 202, 464-471. doi: 10.1111/jac.12179

Osuna, J. L., Baldocchi, D. D., Kobayashi, H., and Dawson, T. E. (2015). Seasonal trends in photosynthesis and electron transport during the Mediterranean summer drought in leaves of deciduous oaks. Tree Physiol. 35, 485-500. doi: 10.1093/treephys/tpv023

Oukarroum, A., Madidi, S. Ø. E., Schansker, G., and Strasser, R. J. (2007). Probing the responses of barley cultivars (Hordeum vulgare L.) by chlorophyll a fluorescence OLKJIP under drought stress and re-watering. Environ. Exp. Bot. 60, 438-446. doi: 10.1016/j.envexpbot.2007.01.002

Ounis, A., Cerovic, Z., Briantais, J., and Moya, I. (2001). Dual-excitation FLIDAR for the estimation of epidermal UV absorption in leaves and canopies. Remote Sens. Environ. 76, 33-48. doi: 10.1016/S0034-4257(00)00190-5

Oxborough, K., and Baker, N. R. (1997). Resolving chlorophyll a fluorescence images of photosynthetic efficiency into photochemical and nonphotochemical components - calculation of $\mathrm{qP}$ and $\mathrm{Fv}$-/Fm-; without measuring Fo. Photosyn. Res. 54, 135-142. doi: 10.1023/A:1005936823310

Papageorgiou, G. C. (2011). Photosystem II fluorescence: slow changesscaling from the past. J. Photochem. Photobiol. B Biol. 104, 258-270. doi: 10.1016/j.jphotobiol.2011.03.008

Parry, M. A., Andralojc, P. J., Khan, S., Lea, P. J., and Keys, A. J. (2002). Rubisco activity: effects of drought stress. Ann. Bot. 89, 833-839. doi: $10.1093 / \mathrm{aob} / \mathrm{mcf} 103$

Peguero-Pina, J. J., Morales, F., Flexas, J., Gil-Pelegrin, E., and Moya, I. (2008). Photochemistry, remotely sensed physiological reflectance index and deepoxidation state of the xanthophyll cycle in Quercus coccifera under intense drought. Oecologia 156, 1-11. doi: 10.1007/s00442-007-0957-y

Peisker, M., and Apel, H. (2001). Inhibition by light of $\mathrm{CO}_{2}$ evolution from dark respiration: comparison of two gas exchange methods. Photosyn. Res. 70, 291-298. doi: 10.1023/A:1014799118368

Pfündel, E. (1998). Estimating the contribution of photosystem I to total leaf chlorophyll fluorescence. Photosyn. Res. 56, 185-195. doi: 10.1023/A:1006032804606

Pfündel, E. E., Ghozlen, N. B., Meyer, S., and Cerovic, Z. G. (2007). Investigating UV screening in leaves by two different types of portable UV fluorimeters reveals in vivo screening by anthocyanins and carotenoids. Photosyn. Res. 93, 205-221. doi: 10.1007/s11120-007-9135-7

Pinheiro, C., and Chaves, M. (2011). Photosynthesis and drought: can we make metabolic connections from available data? J. Exp. Bot. 62, 869-882. doi: $10.1093 /$ jxb/erq340

Poiroux-Gonord, F., Santini, J., Fanciullino, A.-L., Lopez-Lauri, F., Giannettini, J., Sallanon, H., et al. (2013). Metabolism in orange fruits is driven by photooxidative stress in the leaves. Physiol. Plant. 149, 175-187. doi: 10.1111/ppl.12023

Pons, T. L., Flexas, J., Von Caemmerer, S., Evans, J. R., Genty, B., RibasCarbo, M., et al. (2009). Estimating mesophyll conductance to $\mathrm{CO}_{2}$ : methodology, potential errors, and recommendations. J. Exp. Bot. 60, 2217-2234. doi: 10.1093/jxb/erp081

Priault, P., Tcherkez, G., Cornic, G., De Paepe, R., Naik, R., Ghashghaie, J., et al. (2006). The lack of mitochondrial complex I in a CMSII mutant of Nicotiana sylvestris increases photorespiration through an increased internal resistance to $\mathrm{CO}_{2}$ diffusion. J. Exp. Bot. 57, 3195-3207. doi: 10.1093/jxb/erl083

Prihodko, L., and Goward, S. N. (1997). Estimation of air temperature from remotely sensed surface observations. Remote Sens. Environ. 60, 335-346. doi: 10.1016/S0034-4257(96)00216-7

Rahimzadeh-Bajgiran, P., Munehiro, M., and Omasa, K. (2012). Relationships between the photochemical reflectance index (PRI) and chlorophyll fluorescence parameters and plant pigment indices at different leaf growth stages. Photosyn. Res. 113, 261-271. doi: 10.1007/s11120-0129747-4

Reddy, A. R., Chaitanya, K. V., and Vivekanandan, M. (2004). Drought-induced responses of photosynthesis and antioxidant metabolism in higher plants. J. Plant Physiol. 161, 1189-1202. doi: 10.1016/j.jplph.2004.01.013

Ripoll, J., Bertin, N., Bidel, L. P., and Urban, L. (2016b). A user's view of the parameters derived from the induction curves of maximal chlorophyll a fluorescence: perspectives for analyzing stress. Front. Plant Sci. 7:1679. doi: 10.3389/fpls.2016.01679
Ripoll, J., Urban, L., Brunel, B., and Bertin, N. (2016a). Water deficit effects on tomato quality depend on fruit developmental stage and genotype. J. Plant Physiol. 190, 26-35. doi: 10.1016/j.jplph.2015.10.006

Roháçek, K. (2002). Chlorophyll fluorescence parameters: the definitions, photosynthetic meaning, and mutual relationships. Photosynthetica 40, 13-29. doi: 10.1023/A:1020125719386

Ruban, A. V. (2016). Nonphotochemical chlorophyll fluorescence quenching: mechanism and effectiveness in protecting plants from photodamage. Plant Physiol. 170, 1903-1916. doi: 10.1104/pp.15.01935

Rumeau, D., Peltier, G., and Cournac, L. (2007). Chlororespiration and cyclic electron flow around PSI during photosynthesis and plant stress response. Plant Cell Environ. 30, 1041-1051. doi: 10.1111/j.1365-3040.2007.01675.x

Sakai, T., Kagawa, T., Kasahara, M., Swartz, T. E., Christie, J. M., Briggs, W. R., et al. (2001). Arabidopsis nph1 and npl1: blue light receptors that mediate both phototropism and chloroplast relocation. Proc. Natl. Acad. Sci. U.S.A. 98, 6969-6974. doi: 10.1073/pnas.101137598

Sandholt, I., Rasmussen, K., and Andersen, J. (2002). A simple interpretation of the surface temperature/vegetation index space for assessment of surface moisture status. Remote Sens. Environ. 79, 213-224. doi: 10.1016/S0034-4257(01)00274-7

Schansker, G., Toth, S. Z., Holzwarth, A. R., and Garab, G. (2014). Chlorophyll a fluorescence: beyond the limits of the QA model. Photosyn. Res. 120, 43-58. doi: 10.1007/s11120-013-9806-5

Schreiber, U., Schliwa, U., and Bilger, W. (1986). Continuous recording of photochemical and non-photochemical chlorophyll fluorescence quenching with a new type of modulation fluorometer. Photosyn. Res. 10, 51-62. doi: $10.1007 / B F 00024185$

Sharkey, T. D. (2016). What gas exchange data can tell us about photosynthesis? Plant Cell Environ. 39, 1161-1163. doi: 10.1111/pce.12641

Sharkey, T. D., Bernacchi, C. J., Farquhar, G. D., and Singsaas, E. L. (2007). Fitting photosynthetic carbon dioxide response curves for $\mathrm{C} 3$ leaves. Plant Cell Environ. 30, 1035-1040. doi: 10.1111/j.1365-3040.2007.01710.x

Sharkey, T. D., Stitt, M., Heineke, D., Gerhardt, R., Raschke, K., and Heldt, H. W. (1986). Limitation of photosynthesis by carbon metabolism II. $\mathrm{O}_{2}-$ insensitive $\mathrm{CO}_{2}$ uptake results from limitation of triose phosphate utilization. Plant Physiol. 81, 1123-1129. doi: 10.1104/pp.81.4.1123

Shavit, N., and Avron, M. (1963). The effect of ultraviolet light on photophosphorylation and the Hill reaction. Biochim. Biophys. Acta 66, 187-195. doi: 10.1016/0006-3002(63)91185-5

Shikanai, T., and Yamamoto, H. (2017). Contribution of cyclic and pseudo-cyclic electron transport to the formation of proton motive force in chloroplasts. Mol. Plant 10, 20-29. doi: 10.1016/j.molp.2016.08.004

Shinkarev, V. P. (2005). Flash-induced oxygen evolution in photosynthesis: simple solution for the extended S-state model that includes misses, double-hits, inactivation, and backward-transitions. Biophys. J. 88, 412-421. doi: 10.1529/biophysj.104.050898

Sims, D. A., and Gamon, J. A. (2002). Relationships between leaf pigment content and spectral reflectance across a wide range of species, leaf structures and developmental stages. Remote Sens. Environ. 81, 337-354. doi: 10.1016/S0034-4257(02)00010-X

Sinclair, T., Pinter, P. Jr., Kimball, B., Adamsen, F., LaMorte, R., Wall, G., et al. (2000). Leaf nitrogen concentration of wheat subjected to elevated $\left[\mathrm{CO}_{2}\right]$ and either water or $\mathrm{N}$ deficits. Agric. Ecosyst. Environ. 79, 53-60. doi: 10.1016/S0167-8809(99)00146-2

Smirnoff, N. (1993). The role of active oxygen in the response of plants to water-deficit and desiccation. New Phytol. 125, 27-58. doi: 10.1111/j.1469-8137.1993.tb03863.x

Smith, E. L. (1937). The influence of light and carbon dioxide on photosynthesis. J. Gen. Physiol. 20, 807-830. doi: 10.1085/jgp.20.6.807

Smith, T., and Huston, M. (1990). "A theory of the spatial and temporal dynamics of plant communities," in Progress in Theoretical Vegetation Science, eds G. Grabherr, L. Mucina, M. B. Dales, and C. J. F. ter Braak (Dordrecht: Springer), 49-69.

Sperlich, D., Barbeta, A., Ogaya, R., Sabaté, S., and Penuelas, J. (2015). Balance between carbon gain and loss under long-term drought: impacts on foliar respiration and photosynthesis in Quercus ilex L. J. Exp. Bot. 67, 821-833. doi: 10.1093/jxb/erv492

Srivastava, A., and Strasser, R. (1999). Greening of peas: parallel measurements of $77 \mathrm{~K}$ emission spectra, OJIP chlorophyll a fluorescence transient, period four 
oscillation of the initial fluorescence level, delayed light emission, and P700. Photosynthetica 37, 365-392. doi: 10.1023/A:1007199408689

Srivastava, A., Guisséa, B., Greppin, H., and Strasser, R. J. (1997). Regulation of antenna structure and electron transport in Photosystem II of Pisum sativum under elevated temperature probed by the fast polyphasic chlorophyll a fluorescence transient: OKJIP. Biochim. Biophys. Acta 1320, 95-106. doi: 10.1016/S0005-2728(97)00017-0

Stinziano, J. R., Morgan, P. B., Lynch, D. J., Saathoff, A. J., McDermitt, D. K., and Hanson, D. T. (2017). The rapid A-Ci response: photosynthesis in the phenomic era. Plant Cell Environ. 40, 1256-1262. doi: 10.1111/pce.12911

Stirbet, A. (2011). On the relation between the Kautsky effect (chlorophyll a fluorescence induction) and photosystem II: basics and applications of the OJIP fluorescence transient. J. Photochem. Photobiol. B Biol. 104, 236-257. doi: 10.1016/j.jphotobiol.2010.12.010

Strasser, B. J. (1997). Donor side capacity of photosystem II probed by chlorophyll a fluorescence transients. Photosyn. Res. 52, 147-155. doi: 10.1023/A:1005896029778

Strasser, R. J., and Srivastava, A. (1995). Polyphasic chlorophyll a fluorescence transient in plants and cyanobacteria*. Photochem. Photobiol. 61, 32-42. doi: 10.1111/j.1751-1097.1995.tb09240.x

Strasser, R. J., and Stirbet, A. (1998). Heterogeneity of photosystem II probed by the numerically simulated chlorophyll a fluorescence rise (O-J-I-P). Math. Comput. Simul. 48, 3-9. doi: 10.1016/S0378-4754(98)00150-5

Strasser, R. J., Tsimilli-Michael, M., and Srivastava, A. (2004). "Analysis of the chlorophyll a fluorescence transient," in Chlorophyll a Fluorescence, eds G. C. Papageorgiou and Govindjee (Dordrecht: Springer), 321-362.

Stylinski, C. D., Gamon, J. A., and Oechel, W. C. (2002). Seasonal patterns of reflectance indices, carotenoid pigments and photosynthesis of evergreen Chaparral species. Oecologia 131, 366-374. doi: 10.1007/s00442-002-0905-9

Suárez, L., Zarco-Tejada, P. J., Berni, J. A., Gonzalez-Dugo, V., and Fereres, E. (2009). Modelling PRI for water stress detection using radiative transfer models. Remote Sens. Environ. 113, 730-744. doi: 10.1016/j.rse.2008.12.001

Suárez, L., Zarco-Tejada, P. J., Gonzalez-Dugo, V., Berni, J., Sagardoy, R., Morales, F., et al. (2010). Detecting water stress effects on fruit quality in orchards with time-series PRI airborne imagery. Remote Sens. Environ. 114, 286-298. doi: 10.1016/j.rse.2009.09.006

Suárez, L., Zarco-Tejada, P. J., Sepulcre-Canto, G., Pérez-Priego, O., Miller, J., Jimenez-Munoz, J., et al. (2008). Assessing canopy PRI for water stress detection with diurnal airborne imagery. Remote Sens. Environ. 112, 560-575. doi: 10.1016/j.rse.2007.05.009

Sun, J., Feng, Z., Leakey, A. D., Zhu, X., Bernacchi, C. J., and Ort, D. R. (2014). Inconsistency of mesophyll conductance estimate causes the inconsistency for the estimates of maximum rate of Rubisco carboxylation among the linear, rectangular and non-rectangular hyperbola biochemical models of leaf photosynthesis-a case study of $\mathrm{CO}_{2}$ enrichment and leaf aging effects in soybean. Plant Sci. 226, 49-60. doi: 10.1016/j.plantsci.2014. 06.015

Sundby, C., Melis, A., Mäenpää, P., and Andersson, B. (1986). Temperature-dependent changes in the antenna size of Photosystem II. Biochim. Biophys. Acta 851, 475-483. doi: 10.1016/0005-2728(86) 90084-8

Tezara, W., Mitchell, V., Driscoll, S., and Lawlor, D. (1999). Water stress inhibits plant photosynthesis by decreasing coupling factor and ATP. Nature 401, 914-917. doi: 10.1038/44842

Thenot, F., Méthy, M., and Winkel, T. (2002). The Photochemical Reflectance Index (PRI) as a water-stress index. Int. J. Remote Sens. 23, 5135-5139. doi: 10.1080/01431160210163100

Tholen, D., Ethier, G., Genty, B., Pepin, S., and Zhu, X. A. (2012). Variable mesophyll conductance revisited: theoretical background and experimental implications. Plant Cell Environ. 35, 2087-2103. doi: $10.1111 / j .1365-3040.2012 .02538 . x$

Tomas, M., Flexas, J., Copolovici, L., Galmès, J., Hallik, L., Medrano, H., et al. (2013). Importance of leaf anatomy in determining mesophyll diffusion conductance to $\mathrm{CO}_{2}$ across species: quantitative limitations and scaling up by models. J. Exp. Bot. 64, 2269-2281. doi: 10.1093/jxb/ert086

Urban, L., and Alphonsout, L. (2007). Girdling decreases photosynthetic electron fluxes and induces sustained photoprotection in mango leaves. Tree Physiol. 27, 345-352. doi: 10.1093/treephys/27.3.345
Urban, L., and Léchaudel, M. (2005). Effect of leaf-to-fruit ratio on leaf nitrogen content and net photosynthesis in girdled branches of Mangifera indica L. Trees Struc. Funct. 19, 564-571. doi: 10.1007/s00468-005-0415-6

Urban, L., Jegouzo, L., Damour, G., Vandame, M., and Francois, C. (2008). Interpreting the decrease in leaf photosynthesis during flowering in mango. Tree Physiol. 28, 1025-1036. doi: 10.1093/treephys/28.7.1025

Urban, L., Le Roux, X., Sinoquet, H., Jaffuel, S., and Jannoyer, M. (2003). A biochemical model of photosynthesis for mango leaves: evidence for the effect of fruit on photosynthetic capacity of nearby leaves. Tree Physiol. 23, 289-300. doi: 10.1093/treephys/23.5.289

Valentini, R., Epron, D., de Angelis, P., Matteucci, G., and Dreyer, E. (1995). In situ estimation of net CO2 assimilation, photosynthetic electron flow and photorespiration in Turkey oak (Q. cerris L.) leaves: diurnal cycles under different levels of water supply. Plant Cell Environ. 18, 631-640. doi: 10.1111/j.1365-3040.1995. tb00564.x

Van Oijen, M., Schapendonk, A., and Höglind, M. (2010). On the relative magnitudes of photosynthesis, respiration, growth and carbon storage in vegetation. Ann. Bot. 105, 793-797. doi: 10.1093/aob/mcq039

Vigneau, N., Ecarnot, M., Rabatel, G., and Roumet, P. (2011). Potential of field hyperspectral imaging as a non destructive method to assess leaf nitrogen content in Wheat. Field Crops Res. 122, 25-31. doi: 10.1016/j.fcr.2011.02.003

von Caemmerer, S., and Evans, J. (1991). Determination of the average partial pressure of $\mathrm{CO}_{2}$ in chloroplasts from leaves of several C3 plants. Funct. Plant Biol. 18, 287-305.

von Caemmerer, S., and v., Farquhar, G. (1981). Some relationships between the biochemistry of photosynthesis and the gas exchange of leaves. Planta 153, 376-387. doi: 10.1007/BF00384257

von Caemmerer, S., Evans, J. R., Hudson, G. S., and Andrews, T. J. (1994). The kinetics of ribulose-1, 5-bisphosphate carboxylase/oxygenase in vivo inferred from measurements of photosynthesis in leaves of transgenic tobacco. Planta 195, 88-97. doi: 10.1007/BF00206296

von Caemmerer, S., Ghannoum, O., Pengelly, J. J., and Cousins, A. B. (2014). Carbon isotope discrimination as a tool to explore C4 photosynthesis. J. Exp. Bot. 65, 3459-3470. doi: 10.1093/jxb/eru127

Walcroft, A. S., Whitehead, D., Silvester, W. B., and Kelliher, F. M. (1997). The response of photosynthetic model parameters to temperature and nitrogen concentration in Pinus radiata D. Don. Plant Cell Environ. 20, 1338-1348. doi: 10.1046/j.1365-3040.1997.d01-31.x

Warren, C. (2006). Estimating the internal conductance to $\mathrm{CO}_{2}$ movement. Funct. Plant Biol. 33, 431-442. doi: 10.1071/FP05298

Warren, C. (2008). Soil water deficits decrease the internal conductance to $\mathrm{CO}_{2}$ transfer but atmospheric water deficits do not. J. Exp. Bot. 59, 327-334. doi: $10.1093 / \mathrm{jxb} / \mathrm{erm} 314$

Warren, C., and Dreyer, E. (2006). Temperature response of photosynthesis and internal conductance to $\mathrm{CO}_{2}$ : results from two independent approaches. J. Exp. Bot. 57, 3057-3067. doi: 10.1093/jxb/erl067

Wingler, A., Marès, M., and Pourtau, N. (2004). Spatial patterns and metabolic regulation of photosynthetic parameters during leaf senescence. New Phytol. 161, 781-789. doi: 10.1111/j.1469-8137.2004.00996.x

Wong, C. Y., and Gamon, J. A. (2015). Three causes of variation in the photochemical reflectance index (PRI) in evergreen conifers. New Phytol. 206, 187-195. doi: 10.1111/nph.13159

Yamori, W., and Shikanai, T. (2016). Physiological functions of cyclic electron transport around photosystem $\mathrm{I}$ in sustaining photosynthesis and plant growth. Annu. Rev. Plant Biol. 67, 81-106. doi: 10.1146/annurev-arplant-043015-112002

Yang, J. T., Preiser, A. L., Li, Z., Weise, S. E., and Sharkey, T. D. (2016). Triose phosphate use limitation of photosynthesis: short-term and long-term effects. Planta 243, 687-698. doi: 10.1007/s00425-015-2436-8

Yang, J., Zhang, J., Wang, Z., Zhu, Q., and Liu, L. (2001). Water deficitinduced senescence and its relationship to the remobilization of prestored carbon in wheat during grain filling. Agron. J. 93, 196-206. doi: 10.2134/agronj2001.931196x

Yin, X., Struik, P. C., Romero, P., Harbinson, J., Evers, J. B., Van Der Putten, P. E., et al. (2009). Using combined measurements of gas exchange and chlorophyll fluorescence to estimate parameters of a biochemical C3 photosynthesis model: a critical appraisal and a new integrated approach applied to leaves 
in a wheat (Triticum aestivum) canopy. Plant Cell Environ. 32, 448-464. doi: 10.1111/j.1365-3040.2009.01934.x

Yin, X., Sun, Z., Struik, P. C., and Gu, J. (2011). Evaluating a new method to estimate the rate of leaf respiration in the light by analysis of combined gas exchange and chlorophyll fluorescence measurements. J. Exp. Bot. 62, 3289-3299. doi: 10.1093/jxb/err038

Yordanov, I., Goltsev, V., Stefanov, D., Chernev, P., Zaharieva, I., Kirova, M., et al. (2008). Preservation of photosynthetic electron transport from senescenceinduced inactivation in primary leaves after decapitation and defoliation of bean plants. J. Plant Physiol. 165, 1954-1963. doi: 10.1016/j.jplph.2008. 05.003

Yusuf, M. A., Kumar, D., Rajwanshi, R., Strasser, R. J., Tsimilli-Michael, M., and Sarin, N. B. (2010). Overexpression of $\alpha$-tocopherol methyl transferase gene in transgenic Brassica junce plants alleviates abiotic stress: physiological and chlorophyll a fluorescence measurements. Biochim. Biophys. Acta 1797, 1428-1438. doi: 10.1016/j.bbabio.2010. 02.002

Zarco-Tejada, P. J., Gonzalez-Dugo, V., Williams, L., Suarez, L., Berni, J. A., Goldhamer, D., et al. (2013). A PRI-based water stress index combining structural and chlorophyll effects: assessment using diurnal narrow-band airborne imagery and the CWSI thermal index. Remote Sens. Environ. 138, 38-50. doi: 10.1016/j.rse.2013.07.024
Zhang, Y.-L., Hu, Y.-Y., Luo, H.-H., Chow, W. S., and Zhang, W.-F. (2011). Two distinct strategies of cotton and soybean differing in leaf movement to perform photosynthesis under drought in the field. Funct. Plant Biol. 38, 567-575. doi: 10.1071/FP11065

Zhao, D., Reddy, K. R., Kakani, V. G., and Reddy, V. (2005). Nitrogen deficiency effects on plant growth, leaf photosynthesis, and hyperspectral reflectance properties of sorghum. Euro. J. Agron. 22, 391-403. doi: 10.1016/j.eja.2004.06.005

Zlatev, Z. (2009). Drought-induced changes in chlorophyll fluorescence of young wheat plants. Biotechnol. Biotechnol. Equip. 23, 438-441. doi: $10.1080 / 13102818.2009 .10818458$

Conflict of Interest Statement: The authors declare that the research was conducted in the absence of any commercial or financial relationships that could be construed as a potential conflict of interest.

Copyright (c) 2017 Urban, Aarrouf and Bidel. This is an open-access article distributed under the terms of the Creative Commons Attribution License (CC BY). The use, distribution or reproduction in other forums is permitted, provided the original author(s) or licensor are credited and that the original publication in this journal is cited, in accordance with accepted academic practice. No use, distribution or reproduction is permitted which does not comply with these terms. 